\title{
Effects of supplementation with docosahexaenoic acid on reproduction of dairy cows
}

\author{
Letícia D P Sinedino ${ }^{1,2}$, Paula M Honda ${ }^{1}$, Letícia R L Souza ${ }^{1}$, Adam L Lock ${ }^{3}$, Maurice P Boland ${ }^{4}$, \\ Charles R Staples ${ }^{1}$, William W Thatcher ${ }^{1,2}$ and José E P Santos ${ }^{1,2}$ \\ ${ }^{1}$ Department of Animal Sciences, University of Florida, Gainesville, Florida, USA, ${ }^{2}$ DH Barron Reproductive and \\ Perinatal Biology Research Program, University of Florida, Gainesville, Florida, USA, ${ }^{3}$ Department of Animal \\ Science, Michigan State University, East Lansing, Michigan, USA and ${ }^{4}$ Alltech Inc., Nicholasville, Kentucky, USA
}

Correspondence should be addressed to J E P Santos; Email: jepsantos@ufl.edu

\begin{abstract}
The objectives were to determine the effects of supplementing docosahexaenoic acid (DHA)-rich algae on reproduction of dairy cows. Holstein cows were assigned randomly to either a control $(n=373)$ or the same diet supplemented daily with $100 \mathrm{~g} / \mathrm{cow}$ of an algae product containing 10\% DHA (algae, $n=366$ ) from 27 to 147 days postpartum. Measurements included yields of milk and milk components, fatty acids (FA) profiles in milk fat and plasma phospholipids, resumption of ovulation by 57 days postpartum, pregnancy per artificial insemination (AI) and expression of interferon-stimulated genes in leukocytes. Feeding algae increased resumption of estrous cyclicity (77.6 vs $65.9 \%)$ and pregnancy at first $\mathrm{Al}(47.6 \mathrm{vs} 32.8 \%)$ in primiparous cows. Algae increased pregnancy per $\mathrm{Al}$ in all $\mathrm{Al}$ in both primiparous and multiparous cows (41.6 vs $30.7 \%$ ), which reduced days to pregnancy by 22 days (102 vs 124 days) compared with control cows. Pregnant cows fed algae had greater expression of RTP4 in blood leukocytes compared with those in pregnant control cows. Feeding algae increased the incorporation of DHA, eicosapentaenoic acid, conjugated linoleic acid isomers cis-9 trans-11, trans-10 cis-12 and total n-3 FA in phospholipids in plasma and milk fat. Yields of milk and true protein increased by $1.1 \mathrm{~kg} /$ day and $30 \mathrm{~g} /$ day respectively, whereas fat yield decreased $40 \mathrm{~g} / \mathrm{day}$ in algae compared with that in control. Supplementing DHA-rich algae altered the FA composition of lipid fractions and improved reproduction in dairy cows. The benefits on reproduction might be mediated by enhanced embryo development based on changes in interferon-stimulated gene expression.

Reproduction (2017) 153 707-723
\end{abstract}

\section{Introduction}

Fatty acids (FA) perform important roles as regulators of biological processes such as cell membrane stability, gene expression, cell adhesion and proliferation and both intracellular and intercellular transport (Wahle et al. 2003). They are important components of cellular membranes, and changes in tissue FA composition can influence cellular function and gene expression (Abayasekara \& Wathes 1999, Bilby et al. 2006a). Fat supplementation has beneficial effects on reproductive performance of dairy cows (Rodney et al. 2015), and the improvements in fertility caused by fat feeding go beyond an increase in energy intake (Staples et al. 1998). In fact, some of the positive effects seem to be influenced by the type of FA fed (Santos et al. 2008). Also, it is known that fat supplementation can influence lactation performance, and a meta-analysis of the published literature reported an overall increase in milk yield of approximately $1.05 \mathrm{~kg} /$ day in cows that were fed supplemental fat compared with those fed diets without supplemental fat (Rabiee et al. 2012).

One of the long-chain polyunsaturated FA that has been shown to have important biological effects is docosahexaenoic acid (DHA, C22:6 n-3). It is a member of the $n-3$ family of FA and is found in marine fish and algae oils. Algal biomass produced in bulk fermenters provides a consistent, high-quality source of DHA for dairy cattle (Stamey et al. 2012). Incorporation of supplemental n-3 FA into diets of lactating dairy cows can increase their uptake into membrane phospholipids and attenuate innate immunity and inflammatory responses and favor maintenance of pregnancy in dairy cattle (Santos et al. 2008, Silvestre et al. 2011a,b). Feeding DHA, however, may modify the ruminal environment and promote milk fat depression, typically accompanied by increased proportions of conjugated linoleic acid (CLA) and trans-C18:1 FA in milk fat (Hostens et al. 2011). This response can be exacerbated if diets already contain unsaturated FA or are high in starch. 
Altering the dietary intake of FA may promote changes in circulating concentrations of metabolic hormones and ovarian steroids that, in turn, might affect the development and competence of ovarian follicles and/or the composition and secretions of reproductive tissues (Bilby et al. 2006b, Zachut et al. 2008). Changes in FA composition of reproductive tissues concurrent with the altered endocrine milieu might modulate prostaglandin synthesis and improve fertility (Staples et al. 1998). In fact, supplementation of n-3 FA promoted the downregulation of genes related to prostaglandin synthesis in the endometrium and influenced spontaneous release of $\mathrm{PGF}_{2 \alpha}$ in dairy cows (Bilby et al. 2006a, Greco et al. 2014). Several studies reported improvements in pregnancy per $\mathrm{Al}$ (P/Al) or embryo quality in lactating dairy cows supplemented with polyunsaturated FA (Santos et al. 2008, Rodney et al. 2015). Furthermore, lipid uptake and metabolism is likely a key feature regulating conceptus elongation (Ribeiro et al. 2016a,b). Therefore, it is proposed that supplementation with small amounts of n-3 FA such as DHA may improve the development of the conceptus, which in turn would facilitate embryomaternal crosstalk and improve peripheral signaling through complementary actions with interferon-tau secretion that might benefit pregnancy.

Although supplementing diets with FA have been linked to beneficial effects on reproduction in lactating dairy cows, incorporation of large doses of n-3 FA can increase the risk of tissue peroxidation and increase oxidative stress (Gobert et al. 2009, Wullepit et al. 2012). Such negative effects of polyunsaturated $n-3$ FA might be exacerbated if large quantities are fed during the transition period, when lipomobilization is already extensive (Wullepit et al. 2012) or when diets have low content of antioxidant compounds such as vitamin E (Gobert et al. 2009). On the other hand, at low amounts, n-3 FA acts as anti- rather than prooxidant in endothelial vascular cells and placental tissues by reducing inflammation and reducing the formation of reactive oxygen species (Jones et al. 2013, Giordano \& Visioli 2014). Furthermore, although moderate amounts of supplemental fat fed in early lactation does not seem to depress intake (Staples et al. 1998), feeding large quantities of unsaturated FA might suppress appetite (Harvatine \& Allen 2006), which could exacerbate negative energy balance and defeat any benefit to reproduction. Because FA can be used as energy substrate for oocytes and embryos (Sturmey et al. 2009), and they can work as signaling molecules during conceptus elongation (Ribeiro et al. 2016a), it is anticipated that FA with regulatory cellular function might have greater benefit to reproduction. Therefore, strategies to improve reproduction should incorporate strategic feeding of moderate amounts of FA that are expected to have regulatory effects on tissue and cell metabolism.
The hypotheses of the experiment were that supplementation of a lactating dairy cow diet with an algae product rich in DHA to supply a small amount of FA will alter the FA composition of tissues and improve reproduction by increasing P/AI. Therefore, the objectives were to evaluate the effects of supplementing algae rich in DHA on reproductive performance, interferonstimulated gene expression in blood leukocytes and FA composition of plasma and milk in dairy cows. Secondary objectives were to evaluate the effects of supplementing algae rich in DHA on productive performance and plasma concentration of hormones.

\section{Materials and methods}

\section{Ethics approval}

All procedures and protocols for animal handling and care were approved by the University of Florida Institutional Animal Care and Use Committee protocol number ARC 002-14ANS.

\section{Cows and housing}

The experiment was conducted at a commercial dairy farm located in central California comprised of 1800 Holstein cows. Lactating cows $(n=739)$ were enrolled in the experiment between January and July of 2014. Primiparous and multiparous cows were housed separately in free-stall barns identical in design, size, location and orientation and equipped with sprinklers and fans. Cows were offered water and a totally mixed ration in ad libitum amounts to meet or exceed the requirements of lactating Holstein cows weighing $650 \mathrm{~kg}$ and producing $45 \mathrm{~kg}$ of milk per day with $3.5 \%$ fat and $3.2 \%$ true protein when consuming $26 \mathrm{~kg}$ of dry matter per day ( National Research Council 2001). Cows were fed and milked twice daily.

\section{Dietary treatments}

Weekly cohorts of cows were blocked by parity and matched for milk yield recorded during the first 2 weeks of lactation and allocated randomly to receive the control diet $(n=373$ : 115 primiparous cows and 258 multiparous cows) or the same diet supplemented with an algae product containing 10\% docosahexaenoic acid or DHA (Algae, $n=366$ : 105 primiparous cows and 261 multiparous cows). Cows were housed in 6 experimental pens per treatment and the experiment started at $27 \pm 5$ (mean \pm s.D.) days postpartum and lasted 120 days. At enrollment, body condition was evaluated using a $1-5$ scale $(0=$ emaciated and $5=$ obese) according to the Elanco body condition score (BCS) chart (Elanco 2009). For purposes of statistical analyses, cows were categorized as having low $(\leq 2.75)$ or moderate $(\geq 3.00)$ BCS. All cows were identified with colored ear clips according to the assigned diet to ensure accurate pen location.

Diets were the same for both experimental groups, with the exception that cows fed the Algae received individually $100 \mathrm{~g}$ of a supplement (All-G-Rich, Alltech Inc., Nicholasville, 
KY, USA) to supply approximately $10 \mathrm{~g}$ of DHA per cow per day. Upon return from the morning milking, cows were locked with self-lock up stanchions and treated cows were supplemented individually to assure intake of the daily dose of the algae

Table 1 Chemical composition of the diet and algae supplement fed to cows (mean \pm S.D.).

\begin{tabular}{|c|c|c|}
\hline Item & Diet $^{\mathrm{a}}$ & Algae supplement ${ }^{b}$ \\
\hline Dry matter (\%) & $\begin{array}{c}53.1 \pm 1.7 \\
\text { Dry matter basis }\end{array}$ & $97.4 \pm 0.1$ \\
\hline $\begin{array}{l}\text { Net energy of lactation }{ }^{c} \\
(\mathrm{mcal} / \mathrm{kg})\end{array}$ & 1.59 & - \\
\hline Organic matter (\%) & $91.8 \pm 0.1$ & $96.2 \pm 0.1$ \\
\hline Crude protein (\%) & $17.1 \pm 0.3$ & $15.6 \pm 0.2$ \\
\hline Starch $(\%)$ & $23.0 \pm 1.2$ & - \\
\hline $\begin{array}{l}\text { Nonfibrous } \\
\text { carbohydrates }^{\mathrm{d}}(\%)\end{array}$ & $42.0 \pm 0.7$ & $15.3 \pm 2.1$ \\
\hline $\begin{array}{l}\text { Neutral detergent fiber } \\
(\%)\end{array}$ & $30.9 \pm 0.9$ & $2.0 \pm 1.8$ \\
\hline $\begin{array}{l}\text { Acid hydrolysis ether } \\
\text { extract }(\%)\end{array}$ & $4.8 \pm 0.4$ & $63.2 \pm 2.7$ \\
\hline Fatty acids (\%) & $4.1 \pm 0.3$ & $33.2 \pm 3.0$ \\
\hline $\mathrm{Ca}(\%)$ & $0.99 \pm 0.07$ & - \\
\hline $\mathrm{P}(\%)$ & $0.42 \pm 0.02$ & - \\
\hline $\operatorname{Mg}(\%)$ & $0.33 \pm 0.01$ & - \\
\hline K (\%) & $1.40 \pm 0.04$ & - \\
\hline $\mathrm{S}(\%)$ & $0.28 \pm 0.02$ & - \\
\hline $\mathrm{Na}(\%)$ & $0.45 \pm 0.02$ & - \\
\hline $\mathrm{Cl}(\%)$ & $0.62 \pm 0.04$ & - \\
\hline $\begin{array}{l}\text { Dietary cation-anion } \\
\text { difference }^{\mathrm{e}}(\mathrm{mEq} / \mathrm{kg})\end{array}$ & $205 \pm 20$ & - \\
\hline \multicolumn{3}{|c|}{ Fatty acids, $\mathrm{g} / 100 \mathrm{~g}$ of total FA } \\
\hline$<\mathrm{C} 16$ & 0.63 & $5.74 \pm 0.01$ \\
\hline C16:0 & 22.34 & $52.58 \pm 0.36$ \\
\hline C18:0 & 2.55 & $1.41 \pm 0.01$ \\
\hline C18:1 & 27.86 & $0.13 \pm 0.01$ \\
\hline C18:2 cis-9, cis-12 & 40.66 & Not detected \\
\hline $\begin{array}{l}\text { C18:3 cis-9, cis- } 12, \\
\quad \text { cis- } 15\end{array}$ & 3.41 & $0.03 \pm 0.01$ \\
\hline $\begin{array}{l}\text { C20: } 4 \text { cis-5, cis- } 8 \\
\text { cis- } 11, \text { cis- } 14\end{array}$ & Not detected & $0.08 \pm 0.01$ \\
\hline $\begin{array}{l}\text { C20:5 cis-5, cis-8, } \\
\text { cis- } 11, \text { cis- } 14, \\
\text { cis }-17\end{array}$ & Not detected & $0.41 \pm 0.01$ \\
\hline $\begin{array}{l}\text { C22:5 cis- } 4, \text { cis- }-7 \\
\text { cis }-10, \text { cis- } 13, \\
\text { cis }-16\end{array}$ & Not detected & $6.31 \pm 0.06$ \\
\hline $\begin{array}{c}\text { C22: } 6 \text { cis- } 4, \text { cis- }-7 \\
\text { cis }-10, \text { cis- } 13 \\
\text { cis }-16, \text { cis- } 19\end{array}$ & Not detected & $29.98 \pm 0.28$ \\
\hline$n-6$ & 40.66 & $6.56 \pm 0.07$ \\
\hline$n-3$ & 3.41 & $30.50 \pm 0.29$ \\
\hline
\end{tabular}

${ }^{\mathrm{a} D i e t}$ contained (\% dry matter): $27.9 \%$ corn silage, $14.8 \%$ alfalfa hay, $0.3 \%$ wheat straw, $19.8 \%$ stem-flaked corn, $1.9 \%$ citrus pulp, $2.1 \%$ delactose whey, $5.9 \%$ whole cottonseed, $5.1 \%$ dried distiller's grains, $3.3 \%$ soybean hulls, $1.6 \%$ almond hulls, $12.1 \%$ canola meal, $0.7 \%$ molasses, $2.3 \%$ of animal protein blend, and $2.2 \%$ mineral and vitamin premix. Each $\mathrm{kg}$ of the mineral/vitamin premix contained $1800 \mathrm{mg}$ of $\mathrm{Zn}, 450 \mathrm{mg}$ of $\mathrm{Cu}, 1360 \mathrm{mg}$ of $\mathrm{Mn}, 14 \mathrm{mg}$ of Se, $23 \mathrm{mg}$ of I, $14 \mathrm{mg}$ of Co, 180,000 IU of vitamin A, 55,000 IU of vitamin D, and $1800 \mathrm{IU}$ of vitamin E. ${ }^{\mathrm{b}} \mathrm{All}-\mathrm{G}-\mathrm{Rich}$, Alltech. ${ }^{\mathrm{c} C a l c u l a t e d}$ according to National Research Council (2001) and adjusted for $26 \mathrm{~kg}$ of dry matter intake. ${ }^{\mathrm{d} C a l c u l a t e d}$ as: organic matter-(crude protein + (neutral detergent fiber - neutral detergent insoluble protein $)+$ fat $).{ }^{e}$ Calculated as: $(\mathrm{mEq} / \mathrm{kg} \mathrm{K}+\mathrm{mEq} / \mathrm{kg} \mathrm{Na})-(\mathrm{mEq} / \mathrm{kg}$ $\mathrm{Cl}+\mathrm{mEq} / \mathrm{kg}$ of $\mathrm{S})$. supplement. Cows remained in the experiment for 120 days or until they were sold or died, whichever occurred first.

Samples of the diet and the supplement were collected weekly throughout the experiment and stored at $-20^{\circ} \mathrm{C}$. Samples were subsequently dried in air-forced oven at $55^{\circ} \mathrm{C}$ for $48 \mathrm{~h}$ and moisture loss was recorded. Dried samples were ground to pass through a 1.0-mm screen (Wiley Mill, Philadelphia, PA, USA) and later dried at $105^{\circ} \mathrm{C}$ for the determination of dry matter content. Monthly composite of diet samples were analyzed for organic matter $\left(512^{\circ} \mathrm{C}\right.$ for $\left.8 \mathrm{~h}\right)$, neutral detergent fiber using a heat stable $\alpha$-amylase and acid detergent fiber, $N$ using an automated quantitative combustion digestion method, starch using an enzymatic digestion method and subsequent quantification of glucose and minerals using inductively coupled plasma mass spectrometry at a commercial laboratory (Dairyland Laboratories Inc., Arcadia, WI, USA). The crude fat content was analyzed by acid hydrolysis ether extraction at a commercial laboratory (Eurofins Scientific Inc., Des Moines, IA, USA). The algae biomass was produced by heterotrophic fermentation of Schizochytrium limacinum CCAP 4087/2 in closed controlled stainless steel fermenters at the Alltech Algae facility in Winchester, KY, USA. After fermentation, the material was centrifuged to separate the algae from water, and the concentrate algae cells were spray dried and packaged. Table 1 depicts the chemical composition of the diet and the supplemental algae product. The amounts of feed offered and refused per cow were weighed and recorded thrice a week to calculate dry matter intakes.

\section{Milk yield and composition}

Cows were milked twice-daily starting at 05:00 and 15:00 h, and milk weights were recorded electronically at each milking. Milk samples were collected from each cow every 3 weeks and submitted for analysis of fat, true protein, lactose, solidsnot-fat and somatic cells at the local dairy herd improvement laboratory (Hanford, CA).

\section{Fatty acid analyses of milk fat, phospholipid fraction of plasma and feeds}

A subset of 25 cows from each dietary treatment underwent milk and blood collection on day $78 \pm 3$ of the experiment for the determination of FA composition of milk fat and plasma phospholipids.

Milk samples were collected during the first milking of the day and stored at $-20^{\circ} \mathrm{C}$ without preservative. Samples were thawed and centrifuged at $17,800 \mathrm{~g}$ for $30 \mathrm{~min}$ at $8^{\circ} \mathrm{C}$ to collect the fat cake. Milk lipids were extracted, and FA methyl esters were prepared and quantified according to the methods described previously (Lock et al. 2013) and analyzed using gas liquid chromatography. Yield of individual FA (g/day) in milk fat was calculated by using milk fat yield and FA concentration to determine yield on a mass basis using the molecular weight of each FA while correcting for glycerol content and other milk lipid classes (Piantoni et al. 2013).

Blood was sampled by puncture of coccygeal vessels into evacuated tubes containing $\mathrm{K}_{2}$ EDTA (Vacutainer, Becton Dickinson, Franklin Lakes, NJ, USA) and placed immediately 
in ice. Plasma was separated by centrifugation at $2000 \mathrm{~g}$ for $15 \mathrm{~min}$ and stored at $-20^{\circ} \mathrm{C}$ until assayed. Total lipids were extracted from plasma with chloroform and methanol using a modified method of Folch and coworkers (Folch et al. 1957), dried under nitrogen gas and reconstituted in $0.5 \mathrm{~mL}$ chloroform. The phospholipid fraction of plasma lipids was separated from other lipid fractions by solid-phase extraction using a modified method of Agren and coworkers (Agren et al. 1992) as described by Boerman and Lock (2014). Fatty acid methyl esters from the phospholipid fraction were prepared with a modified 2-step transmethylation procedure as described by Boerman and Lock (2014). Fatty acid methyl esters were quantified by gas liquid chromatography as described for milk fat (Lock et al. 2013). The FA content in phospholipids was calculated as $\mathrm{g} / 100 \mathrm{~g}$ of FA or based on the total plasma phospholipids as $\mu \mathrm{g}$ of $\mathrm{FA} / \mathrm{mL}$ of plasma.

Two composite samples of the diet and two of the algae products had FA extracted and FA methyl esters prepared with a modified 2-step transmethylation procedure, followed by quantification by gas liquid chromatography as described previously.

\section{Reproductive management}

All cows had their ovaries evaluated by ultrasonography using a portable ultrasound equipped with a $7.5-\mathrm{MHz}$ transrectal linear transducer (Easi-Scan, BCF Technology, Rochester, MN, USA) on days $43 \pm 3$ and $57 \pm 3$ postpartum to determine the presence or absence of a corpus luteum $(\mathrm{CL})$. Cows without a detected $\mathrm{CL}$ in both examinations were considered anovular, whereas those with a CL in at least one of the two examinations were considered to have resumed estrous cyclicity. Cows were subjected to the Presynch-Ovsynch 56-h protocol for the first postpartum Al. Cows received an i.m. injection of PGF $_{2 \alpha}$ (Lutalyse sterile solution, $25 \mathrm{mg}$ of dinoprost as tromethamine salt, Zoetis, Florham Park, NJ, USA) administered on days $44 \pm 3$ and $58 \pm 3$ postpartum. Cows detected in estrus after 58 days postpartum were inseminated. Cows not observed in estrus were enrolled in the Ovsynch protocol on day $70 \pm 3$ postpartum. The protocol consisted of an i.m. injection

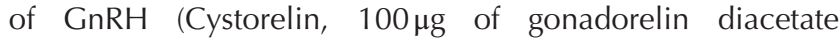
tetrahydrate, Merial Ltd., Duluth, GA, USA) followed 7 days later by an injection of $\mathrm{PGF}_{2 \alpha}$ and a final $\mathrm{GnRH}$ injection $56 \mathrm{~h}$ after the $\mathrm{PGF}_{2 \alpha}$. Cows were inseminated $16 \mathrm{~h}$ after the final $\mathrm{GnRH}$ injection, at $80 \pm 3$ days postpartum. Throughout the experiment, after 58 days postpartum, cows had their tailheads painted using paint sticks (All-Weather Paintstik, LA-CO Industries Inc., Chicago, IL, USA), and detection of estrus was evaluated each morning, based on the removal of the tail chalk. Cows identified in estrus were inseminated on the same morning. On day $32 \pm 3$ after an insemination, cows diagnosed as nonpregnant that had not been re-inseminated were resynchronized with the Ovsynch protocol.

\section{Pregnancy diagnosis and calculation of reproductive responses}

Pregnancy was diagnosed by transrectal ultrasonography on day $32 \pm 3$ after Al. The presence of an amniotic vesicle containing an embryo with heartbeat was used as the determinant of pregnancy. Pregnant cows on day 32 were re-examined for pregnancy by transrectal ultrasonography 4 weeks later, on day $60 \pm 3$ after Al. Pregnancy per Al was calculated by dividing the number of cows diagnosed pregnant at $32 \pm 3$ or $60 \pm 3$ days after $\mathrm{Al}$ by the number of cows receiving $\mathrm{AI}$. Pregnancy loss was calculated as the number of cows that lost pregnancy between days $32 \pm 3$ and $60 \pm 3$ after $\mathrm{Al}$ divided by the number of cows diagnosed pregnant on day $32 \pm 3$ after AI. Cows that were detected in estrus before pregnancy diagnosis were re-inseminated and considered as nonpregnant. For the time to pregnancy, the interval from calving to pregnancy or censoring was used. Cows that remained nonpregnant by 120 days in the experiment and those nonpregnant that were sold or died before 120 days in the experiment were censored. For the analysis of time to pregnancy, pregnancy was based on the diagnosis at $60 \pm 3$ days after insemination.

\section{Concentrations of progesterone in plasma and ovarian ultrasound}

Seventy-eight cows, 39 control (14 primiparous cows and 25 multiparous cows) and 39 Algae cows (8 primiparous cows and 31 multiparous cows) that underwent the Presynch-Ovsynch protocol had blood sampled during the synchronization protocol for the assessment of concentrations of progesterone in plasma. All cows had a synchronized estrous cycle based on ovulation to the initial $\mathrm{GnRH}$, regression of the $\mathrm{CL}$ after the $\mathrm{PGF}_{2 \alpha}$ and ovulation within $48 \mathrm{~h}$ after the final GnRH of the Ovsynch protocol. Ovulation was based on ultrasonographic evaluation of the ovaries, and CL regression based on a decline in progesterone concentration in plasma to less than $1.0 \mathrm{ng} / \mathrm{mL}$ $72 \mathrm{~h}$ after $\mathrm{PGF}_{2 \alpha}$ treatment, when $\mathrm{Al}$ was performed. Ovaries were scanned by ultrasound (Aloka SSD-500 equipped with a 7.5 MHz linear transducer, Aloka Co., Tokyo, Japan) during the Ovsynch protocol concurrent with the injections of the first $\mathrm{GnRH}, \mathrm{PGF}_{2 \alpha^{\prime}}$ second $\mathrm{GnRH}$ and $48 \mathrm{~h}$ after Al. Follicle and $\mathrm{CL}$ location and diameter were recorded. Ovulation in response to the first GnRH of the Ovsynch was based on the presence of a follicle $\geq 10 \mathrm{~mm}$ in diameter and appearance of a new $\mathrm{CL}$ in the same ovary on the day of the $\mathrm{PGF}_{2 \alpha}$ treatment.

Additional blood was sampled from 149 cows, 77 control (22 primiparous cows and 55 multiparous cows) and 72 Algae (22 primiparous cows and 50 multiparous cows) on days 2, 4, 6, 8, 10, 12, 14, 16, 17, 18 and 19 after Al. Only cows that had a synchronized ovulation based on low concentration of progesterone $(<1.0 \mathrm{ng} / \mathrm{mL})$ on day 2 after $\mathrm{Al}$ and high concentrations of progesterone $(>1.0 \mathrm{ng} / \mathrm{mL})$ on days 6 and 8 after $\mathrm{Al}$ remained for statistical analyses. Of the initial sampled cows, 9 control (4 primiparous cows and 5 multiparous cows) and 12 Algae (6 primiparous cows and 6 multiparous cows) were removed because of asynchronous estrous cycle. The remaining sampled cows (68 control and 60 Algae) were evaluated for pregnancy on day 32 after Al and characterized as nonpregnant ( $n=64,40$ control and 24 Algae) and pregnant cows ( $n=64,28$ control and 36 Algae).

Blood was handled as described previously. Progesterone concentrations in plasma were evaluated by radioimmunoassay using a commercial kit (Coat-a-Count, Siemens Healthcare 
Diagnostics). Plasma harvested from cows on days 4 ( 1.5 ng/ $\mathrm{mL})$ and $10(\sim 5.5 \mathrm{ng} / \mathrm{mL})$ of the estrous cycle were incorporated into each assay and used to calculate the CV. The intra- and inter-assay CVs were 8.9 and $11.8 \%$ respectively.

\section{Concentrations of insulin and IGF-1 in plasma before and after treatment with bovine somatotropin}

Forty-eight cows, 24 control (7 primiparous cows and 17 multiparous cows) and 24 Algae cows (7 primiparous cows and 17 multiparous cows), had blood sampled from coccygeal vessels to evaluate the concentrations of insulin and IGF-1 in plasma. Within each treatment, half of the cows received treatment with $500 \mathrm{mg}$ of bovine somatotropin (bST, Posilac, sometribove zinc suspension for injection, Elanco Animal Health, Greenfield, IN, USA) and half received an injection of saline. Samples were collected in all cows starting at $62 \pm 3$ days postpartum and, in cows receiving bST, treatment was initiated 6 days later, at $68 \pm 3$ days postpartum and repeated 11 days later. Blood was sampled in all 48 cows on days $-6,-2,2,6,10,14,18$ and 22 relative to bST treatment.

Blood was handled as described previously. Concentrations of total IGF-1 were determined by a commercial ELISA kit (Quantikine ELISA Human IGF1 Immunoassay, R\&D Systems) as described previously (Ribeiro et al. 2014). Plasma concentrations of insulin were determined by a commercial bovine ELISA kit (Mercodia Bovine Insulin ELISA, Mercodia AB, Uppsala, Sweden). The intra- and inter-assay CVs were 6.5 and $10.5 \%$ for IGF-1 and $2.3 \%$ and $4.0 \%$ for insulin.

\section{Peripheral blood leukocyte isolation and mRNA extraction}

Blood was sampled from coccygeal vessels on day 19 after Al from 116 pregnant cows, 49 control and 67 Algae, for isolation of leukocytes as described by Ribeiro and coworkers (Ribeiro et al. 2014). Samples of blood also were collected from 9 nonpregnant cows ( 5 control and 4 Algae) that served as reference in the analyses. The pellets of isolated leukocytes were suspended with $0.8 \mathrm{~mL}$ of TRIzol (Molecular Research Center Inc., Cincinnati, $\mathrm{OH}$, USA), transferred to microcentrifuge tubes and stored at $-80^{\circ} \mathrm{C}$ until RNA extraction. On the day of RNA extraction, samples were removed from the freezer and $200 \mu \mathrm{L}$ of chloroform were added for each $1 \mathrm{~mL}$ of solution. The microcentrifuge tubes were homogenized vigorously by hand for $15 \mathrm{~s}$ and incubated at room temperature for $3 \mathrm{~min}$. Tubes were centrifuged at $12,000 \mathrm{~g}$ for $15 \mathrm{~min}$ at $4{ }^{\circ} \mathrm{C}$ for the removal of the upper aqueous solution containing RNA. Subsequent RNA extraction was performed using a commercial kit (Purelink RNA Mini Kit, Cat. No. 12183018A; Life Technologies) according to the manufacturer's instructions.

\section{Real-time $q P C R$}

Isolated RNA was evaluated for concentration using a NanoDrop 2000 spectrophotometer (Thermo Scientific), and integrity was assessed using the Agilent 2100 Bioanalyzer (Agilent Technologies) before assays. A total of $250 \mathrm{ng}$ of RNA were reverse transcribed to $\mathrm{cDNA}$ using a commercial kit
Table 2 Gene, primer orientation, primer sequence $\left(5^{\prime}-3^{\prime}\right)$ and National Center for Biotechnology Information (NCBI) accession number and sequence for primers used in RT-qPCR assays.

\begin{tabular}{|c|c|c|c|}
\hline Gene & Primer & Sequence $\left(5^{\prime}-3^{\prime}\right)$ & NCBI sequence \\
\hline \multirow[t]{2}{*}{$A C T B$} & Forward & CTGGACTTCGAGCAGGAGAT & AY141970 \\
\hline & Reverse & GATGTCGACGTCACACTTC & \\
\hline \multirow[t]{2}{*}{ ISG 15} & Forward & GGTATCCGAGCTGAAGCAGTT & NM_174366 \\
\hline & Reverse & АССТСССТGСТGTCAAGGT & \\
\hline \multirow[t]{2}{*}{ RPL19 } & Forward & ATTGACCGCCACATGTATCA & NM_001040516 \\
\hline & Reverse & GCGTGCTTCCTTGGTCTTAG & \\
\hline \multirow[t]{2}{*}{ RTP4 } & Forward & TTCTCСССАGAAAGCAGCAA & BC105539 \\
\hline & Reverse & TTCACAGTTGGCCTTGTCATG & \\
\hline
\end{tabular}

(High-capacity cDNA Reverse Transcription Kit, Cat. No. 4368813, Applied Biosystems) following manufacturer's instructions. Real-time qPCR was performed using SYBR Green PCR Master Mix (Cat. No. 4385614, Applied Biosystems) and the ABI 7300 Real-Time PCR System (Applied Biosystems). After an initial activation at $60^{\circ} \mathrm{C}$ for $2 \mathrm{~min}$ followed by denaturation at $95^{\circ} \mathrm{C}$ for $10 \mathrm{~min}$, the amplification protocol followed 40 cycles of $95^{\circ} \mathrm{C}$ for $15 \mathrm{~s}$ and $60^{\circ} \mathrm{C}$ for $1 \mathrm{~min}$. Each sample was evaluated in duplicate, and the specificity for amplification was verified by melting curve analysis. Primer efficiency averaged $102 \%$. Four genes were investigated (Table 2) including two reference genes $\beta$-actin $(A C T B)$ and ribosomal protein L19 (RPL19), and two target genes, ubiquitin-like IFN-stimulated gene 15-kDa protein (IGS15) and chemosensory receptor transporter protein 4 (RTP4).

\section{Statistical analyses}

The experiment followed a randomized block design. Weekly cohort of cows were blocked by parity and randomly assigned to control or Algae. Continuous variables were analyzed by ANOVA using the MIXED procedure of SAS, version 9.4 (SAS Institute Inc., Carry, NC, USA). Every response for continuous variables was evaluated for distribution of residuals and homogeneity of variance after model fitting. Data with violation of the assumptions of normality after model fitting were subjected to Box-Cox power transformation using the TRANSREG procedure of SAS before the final statistical analysis. The least-squares means and respective standard errors of transformed data were back transformed for presentation according to Jørgensen and Pedersen (1998). The statistical models included the fixed effects of treatment (control vs Algae), parity (primiparous cows vs multiparous cows) and the interaction between treatment and parity. Individual milk yield average during the first 14 days postpartum was used as covariate for analyses of production performance. For repeated measurements within experimental unit, the effect of time and the interaction between treatment and time were included as fixed effects, and cow nested within treatment was the random effect for testing the effect of treatment. For the subset of cows included in the analyses of responses to bST, the models also included the fixed effects of bST (yes or no) and the interactions between treatment and bST, bST and day and treatment and bST and day. For analysis of concentrations of progesterone, the fixed effects of pregnancy on day 32, treatment and the interactions between treatment and pregnancy, pregnancy and 
day and treatment and pregnancy and day were also considered in the model. The Kenward-Roger method was used to obtain the approximate degrees of freedom. The covariance structure that resulted in the best fitted model based on the smallest Akaike's criterion was selected for the analysis of data with repeated measurements.

Binary data were analyzed by multivariable logistic regression using the GLIMMIX procedure of SAS. The models included the fixed effects of treatment, parity, interaction between treatment and parity and the BCS at experimental enrollment. Time to pregnancy was analyzed by the Cox's proportional hazard model with the PHREG procedure of SAS. The time variable considered was the number of days between calving and the day of $\mathrm{Al}$ that resulted in pregnancy or the day in which cows were censored from the analyses (i.e. cows sold, dead or remained nonpregnant at the end of the experiment). Models included the effects of treatment, parity, interaction between treatment and parity and BCS of cows at enrollment. The adjusted hazard ratio (AHR) and 95\% confidence interval $(\mathrm{Cl})$ were computed. The median and mean days to pregnancy were obtained from the LIFETEST procedure of SAS.

Quantitative PCR data are presented using the comparative method developed by Livak and Schmittgen (2001) using nonpregnant cows as reference for relative expression of mRNA abundance, which was set to the relative value of 1 . The delta cycle threshold (CT) values for each target gene were obtained after normalization of CT value of the gene with the geometric mean of CT values from the 2 reference genes. Data were analyzed using the delta CT with the MIXED procedure of SAS fitting a model with the fixed effects of treatment, parity and the interaction between treatment and parity. The deltadelta CT was obtained from delta CT least-squares means differences of pairwise comparisons among treatments and the reference nonpregnant cows (Yuan et al. 2006). Pairwise comparisons were adjusted by the Tukey's honest significant difference. The relative expression values were obtained by raising the PCR amplification efficiency $(E=2)$ to the power delta-delta CT (Yuan et al. 2006). Confidence limits for graphical representation of relative expression were generated from the lower and upper $95 \% \mathrm{Cl}$ obtained for delta CT leastsquares means differences as described by Yuan and coworkers (Yuan et al. 2006).

Treatment differences with $P \leq 0.05$ were considered significant and those with $0.05<P \leq 0.10$ were considered as tendencies.

\section{Results \\ Reproductive responses}

An interaction $(P=0.04)$ between treatment and parity was detected for resumption of estrous cycles by 58 days postpartum because feeding Algae increased the proportion of primiparous cows that resumed estrous cyclicity, whereas no difference was detected for multiparous cows (Table 3). Regardless of dietary treatment, estrous cyclicity at 58 days postpartum increased $(P<0.01)$ in cows that had moderate BCS at experiment enrollment compared with those with low BCS (77.9 vs $68.8 \%$ ). A greater proportion of cows fed Algae tended $(P=0.09)$ to be detected in estrus after treatment with $\mathrm{PGF}_{2 \alpha}$ than control cows (49.3 vs $42.2 \%)$. Also, detection of estrus increased $(P=0.02)$ in primiparous cows compared with multiparous cows (50.9 vs 39.9\%), but BCS at experiment enrollment or the interaction between treatment and BCS did not affect the detection of estrus. The day postpartum at first Al did not differ with treatment, parity or BCS (Table 3).

Pregnancy at first Al on day 32 was affected $(P=0.04)$ by the interaction between treatment and parity. Feeding Algae improved $\mathrm{P} / \mathrm{Al}$ at first $\mathrm{Al}$ in primiparous cows, but had no effect on multiparous cows when the diagnosis was performed 32 days after the first $\mathrm{Al}$ (Table 3). Likewise, this interaction tended $(P=0.07)$ to be significant at 60 days after the first AI. The BCS at

Table 3 Effects of feeding an algae product rich in docosahexaenoic acid on reproductive performance of Holstein cows.

\begin{tabular}{|c|c|c|c|c|c|c|c|c|}
\hline \multirow[b]{3}{*}{ Item $^{c}$} & \multicolumn{4}{|c|}{ Treatment $^{\mathrm{a}}$} & \multirow[b]{3}{*}{ S.E.M. } & \multirow{2}{*}{\multicolumn{3}{|c|}{$P$ value ${ }^{b}$}} \\
\hline & \multicolumn{2}{|c|}{ Control } & \multicolumn{2}{|c|}{ Algae } & & & & \\
\hline & Primiparous & Multiparous & Primiparous & Multiparous & & TRT & Parity & TRT $\times$ parity \\
\hline Cows $(n)$ & 115 & 258 & 105 & 261 & - & - & - & - \\
\hline Estrous cyclic (\%) & 65.9 & 76.6 & 77.6 & 73.4 & - & 0.27 & 0.44 & 0.04 \\
\hline Estrus (\%) & 44.7 & 39.7 & 56.9 & 41.7 & - & 0.09 & 0.02 & 0.23 \\
\hline Day at first Al & 71.8 & 71.5 & 69.3 & 71.6 & 1.2 & 0.15 & 0.35 & 0.12 \\
\hline \multicolumn{9}{|l|}{$\mathrm{P} / \mathrm{Al}$ at first $\mathrm{Al}(\%)$} \\
\hline Day 32 & 33.7 & 38.7 & 49.3 & 36.6 & - & 0.11 & 0.39 & 0.04 \\
\hline Day 60 & 32.8 & 35.3 & 47.6 & 34.7 & - & 0.09 & 0.25 & 0.07 \\
\hline $\mathrm{PL}$ at first $\mathrm{Al}(\%)$ & 2.7 & 8.2 & 4.2 & 5.0 & - & 0.97 & 0.34 & 0.47 \\
\hline \multicolumn{9}{|l|}{$\mathrm{P} / \mathrm{Al}$ at all $\mathrm{Al}(\%)$} \\
\hline Day 32 & 27.3 & 37.9 & 46.9 & 40.3 & - & $<0.01$ & 0.48 & $<0.01$ \\
\hline Day 60 & 26.8 & 35.0 & 45.1 & 38.1 & - & $<0.01$ & 0.73 & 0.01 \\
\hline $\mathrm{PL}$ at all $\mathrm{Al}(\%)$ & 1.9 & 7.2 & 3.8 & 5.2 & - & 0.77 & 0.18 & 0.40 \\
\hline
\end{tabular}

${ }^{\mathrm{a}}$ Cows in control and Algae were fed the same diet but Algae was supplemented with $100 \mathrm{~g} / \mathrm{cow}$ per day of an algae product rich in docosahexaenoic acid. ${ }^{\mathrm{C} T R T}=$ effect of treatment (control vs Algae); Parity $=$ effect of parity (primiparous vs multiparous); TRT $\times$ parity $=$ interaction between TRT and parity. ' Estrous cyclic at 58 days postpartum; estrus = detection of estrus between 58 and 70 days postpartum; $\mathrm{P} / \mathrm{Al}=$ pregnancy per Al; PL = pregnancy loss. 


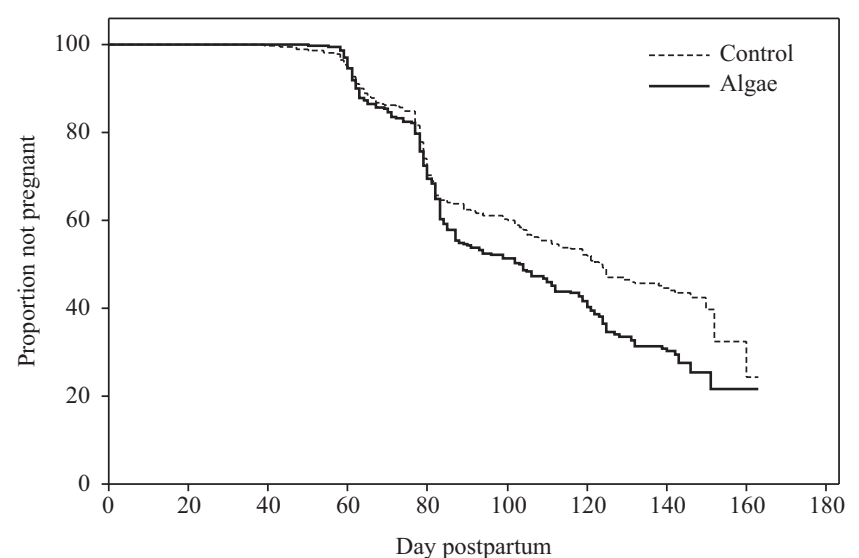

Figure 1 Survival curves for interval from calving to pregnancy in cows fed control (dotted line) or Algae (solid line). Control and Algae cows were fed the same diet, but Algae was supplemented with $100 \mathrm{~g} / \mathrm{cow}$ per day of an algae product rich in docosahexaenoic acid. Cows fed Algae became pregnant faster $(P<0.01)$ than those fed control (adjusted hazard ratio $=1.39 ; 95 \% \mathrm{Cl}=1.14-1.70$ ). The median and mean ( \pm S.E.M.) days to pregnancy were respectively 124 (95\% confidence interval $(\mathrm{Cl})=108-141)$ and $117.9 \pm 2.2$ for control and $102(95 \% \mathrm{Cl}=87-112)$ and $106.9 \pm 1.9$ for Algae.

experiment enrollment tended ( $P=0.07$ ) to influence $\mathrm{P} /$ AI because cows with moderate BCS had better P/AI than those with low BCS (43.2 vs $35.9 \%$ ), and this response was detected regardless of the treatment. Pregnancy loss between gestation days 32 and 60 was not affected by treatment or by the interaction between treatment and parity and averaged $4.7 \%$.

Pregnancy per Al for all inseminations increased $(P<0.01)$ in Algae compared with control cows on days 32 (43.6 vs $32.3 \%)$ and 60 (41.6 vs $30.7 \%)$ after Al (Table 3). The benefit of feeding Algae was greater in primiparous cows than that in multiparous cows based on the interaction $(P<0.01)$ between treatment and parity. Cows with BCS at experiment enrollment classified as moderate tended $(P=0.09)$ to have greater $\mathrm{P} / \mathrm{Al}$ at all inseminations than those with low BCS (40.6 vs $34.4 \%$ ), and this response was irrespective of dietary treatment. No difference in pregnancy loss was detected due to treatment, parity, BCS and interactions between treatment and parity or treatment and BCS.
Feeding Algae increased $(P<0.01)$ the rate of pregnancy compared with control by $39 \%$ (Fig. 1, $\mathrm{AHR}=1.39,95 \% \mathrm{Cl}=1.14-1.70$ ), which reduced the median days to pregnancy by approximately 22 days. The increase in pregnancy rate in cows fed Algae was detected in both parity groups, but the benefit was greater in primiparous cows than that in multiparous cows based on the interaction $(P=0.02)$ between treatment and parity (Table 4). Within primiparous cows, Algae almost doubled $(P<0.01)$ the rate of pregnancy $(\mathrm{AHR}=1.99$, $95 \% \mathrm{Cl}=1.38-2.86)$, whereas in multiparous cows, feeding Algae tended $(P=0.10)$ to increase the rate of pregnancy by $22 \%(\mathrm{AHR}=1.22,95 \% \mathrm{Cl}=0.96-1.55)$.

\section{Diameter of the pre-ovulatory follicle and concentrations of hormones in plasma}

The diameter of the ovulatory follicle on day 9 of the Ovsynch protocol did not differ $(P=0.83)$ between treatments and averaged $15.4 \pm 0.60 \mathrm{~mm}$. Multiparous cows had a greater $(P=0.05)$ mean pre-ovulatory follicle diameter than those in primiparous cows (16.2 vs $14.6 \pm 0.70 \mathrm{~mm})$, regardless of treatment. The presence of a $\mathrm{CL}$ in the beginning of the Ovsynch protocol did not affect $(P=0.14)$ the diameter of the pre-ovulatory follicle.

Concentrations of progesterone in plasma on day 7 of the Ovsynch protocol did not differ $(P=0.13)$ between treatments (control $=6.36$ and Algae $=5.24 \pm 0.55 \mathrm{ng} / \mathrm{mL}$ ). Cows that had a CL at the beginning of the Ovsynch protocol had greater $(P=0.02)$ concentrations of progesterone on day 7 of the protocol compared with those that did not have a $\mathrm{CL}(\mathrm{CL}=6.59$ vs no $\mathrm{CL}=5.00 \pm 0.53 \mathrm{ng} / \mathrm{mL}$ ), and this effect was not influenced by treatment. Parity, treatment or interaction between treatment and parity did not influence plasma concentrations of progesterone during the Ovsynch protocol. Mean concentrations of progesterone in plasma during the first 19 days after Al did not differ between treatments and averaged $5.02 \pm 0.18$ and $4.83 \pm 0.19$ for control and Algae respectively (Fig. 2). Cows that were pregnant on day 32 after $\mathrm{Al}$ had greater $(P<0.001)$ concentrations of progesterone than nonpregnant cows, but differences were only detected

Table 4 Cox's proportional hazard model for time to pregnancy in Holstein according to treatment and parity.

\begin{tabular}{|c|c|c|c|c|c|}
\hline \multirow[b]{2}{*}{ Treatment $^{1}$} & \multirow[b]{2}{*}{ Pregnant $(\%)$} & \multicolumn{2}{|c|}{ Days to pregnancy } & \multirow[b]{2}{*}{ Adjusted $\mathbf{H R}^{\mathbf{3}}$ (95\% Cl) } & \multirow[b]{2}{*}{$P$-value } \\
\hline & & Median $(95 \% \mathrm{Cl})^{2}$ & Mean \pm S.E.M. & & \\
\hline Control primiparous $(n=115)$ & 42.6 & $142^{\mathrm{c}, 4}$ & $113.1 \pm 3.2$ & Reference & - \\
\hline Control multiparous $(n=258)$ & 51.6 & $121^{\text {bc }}(104-138)$ & $116.5 \pm 2.7$ & $1.24(0.89-1.73)$ & 0.20 \\
\hline Algae primiparous $(n=105)$ & 66.7 & $83^{a}(80-90)$ & $94.0 \pm 2.9$ & $1.99(1.38-2.86)$ & $<0.01$ \\
\hline Algae multiparous $(n=261)$ & 57.5 & $111^{\mathrm{b}}(96-121)$ & $110.2 \pm 2.2$ & $1.48(1.06-2.06)$ & 0.02 \\
\hline
\end{tabular}

a,b,c Superscripts within the same column differ $(P<0.05)$. ${ }^{1}$ Cows in control and Algae were fed the same diet but Algae was supplemented with $100 \mathrm{~g} / \mathrm{cow}$ per day of an algae product rich in docosahexaenoic acid. Effects of treatment $(P<0.01)$, parity $(P=0.20)$ and interaction between treatment and parity $(P=0.02)$. Within primiparous, effect of treatment $(P<0.01$; adjusted $\mathrm{HR}=1.99,95 \% \mathrm{Cl}=1.38-2.86)$. Within multiparous, effect of treatment $(P=0.10$; adjusted $\mathrm{HR}=1.22,95 \% \mathrm{Cl}=0.96-1.55) .{ }^{2} \mathrm{Cl}$, confidence interval. ${ }^{3} \mathrm{HR}$, hazard ratio. ${ }^{4}$ Because the median days to pregnancy were close to the end of the experiment ( $147 \pm 5$ days postpartum), only the lower limit for the $95 \% \mathrm{Cl}$ was available for control primiparous (119 days). The upper limit was not calculated. 


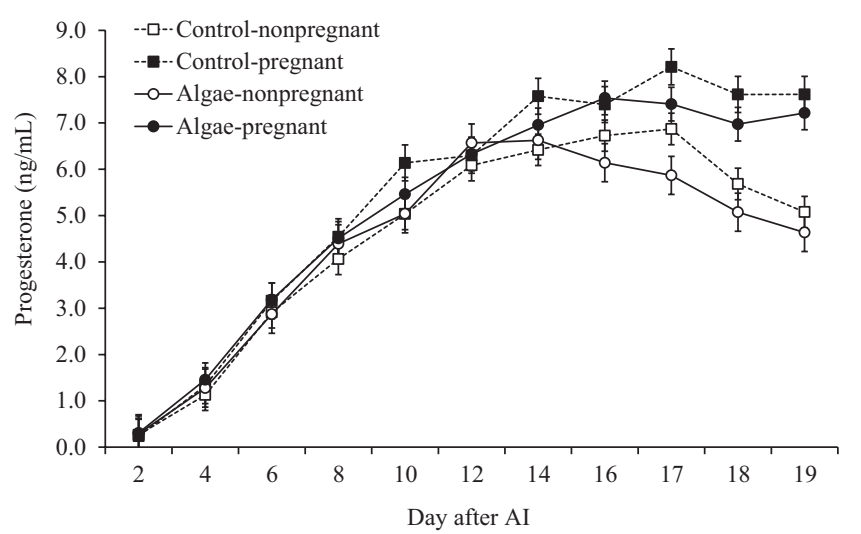

Figure 2 Progesterone concentrations in plasma after Al. Cows were fed the same diet as control (square symbol dashed line, $n=68$, 40 nonpregnant and 28 pregnant) or Algae (circle symbol solid line, $n=60,24$ nonpregnant and 36 pregnant), but Algae cows were supplemented with $100 \mathrm{~g} / \mathrm{cow}$ per day of an algae product rich in docosahexaenoic acid. Effects of treatment $(P=0.47)$, day $(P<0.001)$, pregnancy $(P<0.001)$ and interactions between treatment and day $(P=0.19)$, treatment and pregnancy $(P=0.81)$, pregnancy and day $(P<0.001)$ and treatment and pregnancy and day $(P=0.79)$.

after day 14 after insemination. Parity did not affect the concentrations of progesterone. No interactions were detected between treatment and day, treatment and pregnancy and treatment and parity.

An interaction between dietary treatment and bST was detected for plasma concentrations of insulin (Fig. 3A and B). Control cows not treated with bST had greater $(P=0.04)$ mean concentrations of insulin compared with Algae cows not treated with bST (control $=0.79 \pm 0.08$ vs Algae $=0.57 \pm 0.06$ ), whereas dietary treatment did not affect insulin concentrations in plasma of cows injected with bST (control $=0.51 \pm 0.05$ vs Algae $=0.57 \pm 0.06$ ). Concentrations of IGF-1 increased (effect of week, $P<0.001$ ) after bST treatment and a tendency for interaction $(P=0.08)$ between treatment and bST on concentrations of IGF-1 (Fig. 3C and D) was detected. Concentrations of IGF-1 did not differ between dietary treatments in cows not receiving bST and averaged $97.7 \mathrm{ng} / \mathrm{mL}$ (Fig. 3C). However, when cows were treated with bST, those receiving Algae tended ( $P=0.08)$ to have greater concentrations of IGF-1 than control cows (control-bST $=102.9 \pm 6.7 \mathrm{ng} / \mathrm{mL}$ vs Algae-bST $=118.7 \pm 7.7 \mathrm{ng} / \mathrm{mL}$, Fig. 3D).

\section{Expression of interferon-stimulated genes in leukocytes on day 19 after $A I$}

As anticipated, the normalized expression of interferonstimulated genes in peripheral blood leukocytes on day 19 after $\mathrm{Al}$ increased $(P<0.0001)$ with pregnancy (Fig. 4). The mRNA abundance for ISG15 did not differ between treatments (Fig. 4A and C), but it was greater $(P=0.03)$ in pregnant primiparous cows than in pregnant multiparous cows (Fig. 4C). Treatment affected $(P=0.02)$ the expression of RTP4, which was greater in leukocytes of pregnant cows fed Algae than control (Fig. 4B). Expression of $R T P 4$ was greater $(P \leq 0.01)$ in primiparous compared with multiparous cows (Fig. 4D). The increase in mRNA normalized the expression for RTP4 when feeding Algae was observed in both primiparous and multiparous cows (Fig. 4D).

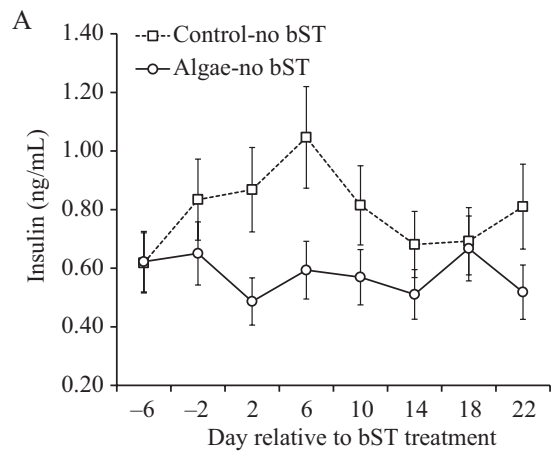

C

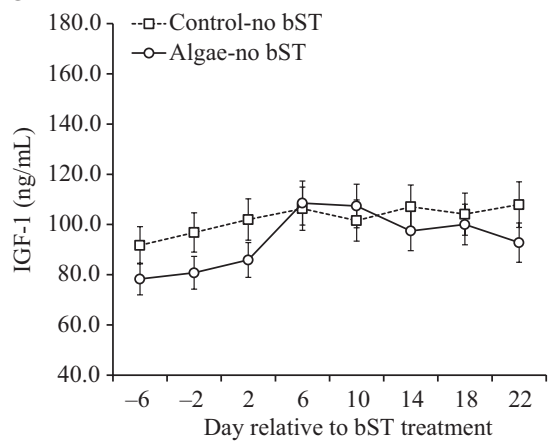

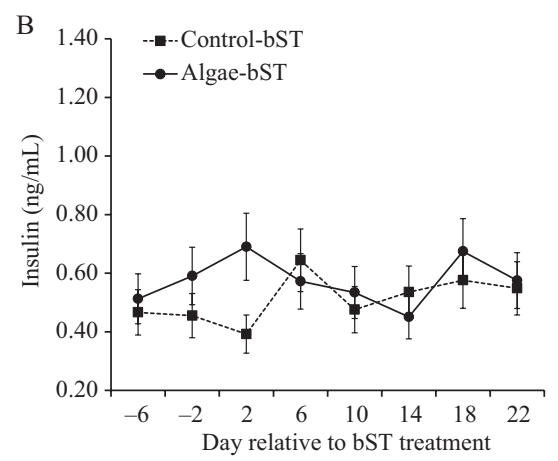

D

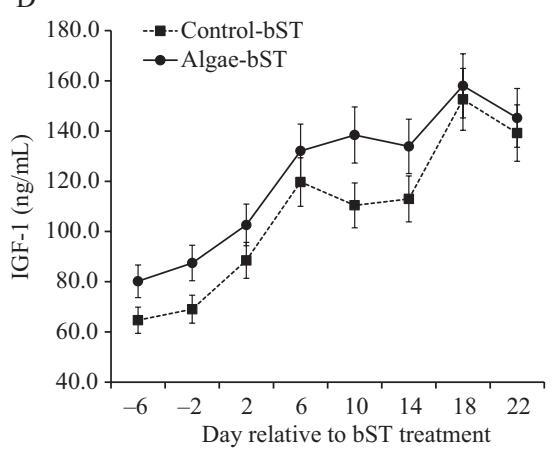

Figure 3 Concentrations of insulin (panels $\mathrm{A}$ and $\mathrm{B}$ ) and insulin-like growth factor (IGF) 1 (panels C and D) in plasma. Cows were fed the same diet as control (square dashed line, $n=24$ ) or Algae (circle solid line, $n=24$ ), but Algae cows were supplemented with $100 \mathrm{~g} / \mathrm{cow}$ per day of an algae product rich in docosahexaenoic acid. Within each treatment, half of the cows ( $n=12 /$ treatment) received bST on days 0 and 11. Panels A and C represent results from cows injected with saline, whereas panels B and D represent results of cows injected with bST. Insulin, effects of treatment $(P=0.33)$, day $(P=0.19)$, bST $(P=0.03)$ and interactions between treatment and day $(P=0.36)$, treatment and bST $(P=0.04)$ and treatment and bST and day $(P=0.22)$. Insulin-like growth factor- 1 , effects of treatment $(P=0.69)$, day $(P<0.001)$, bST $(P=0.06)$ and interactions between treatment and day $(P=0.29)$, treatment and bST $(P=0.08)$ and treatment and bST and day $(P=0.23)$. 

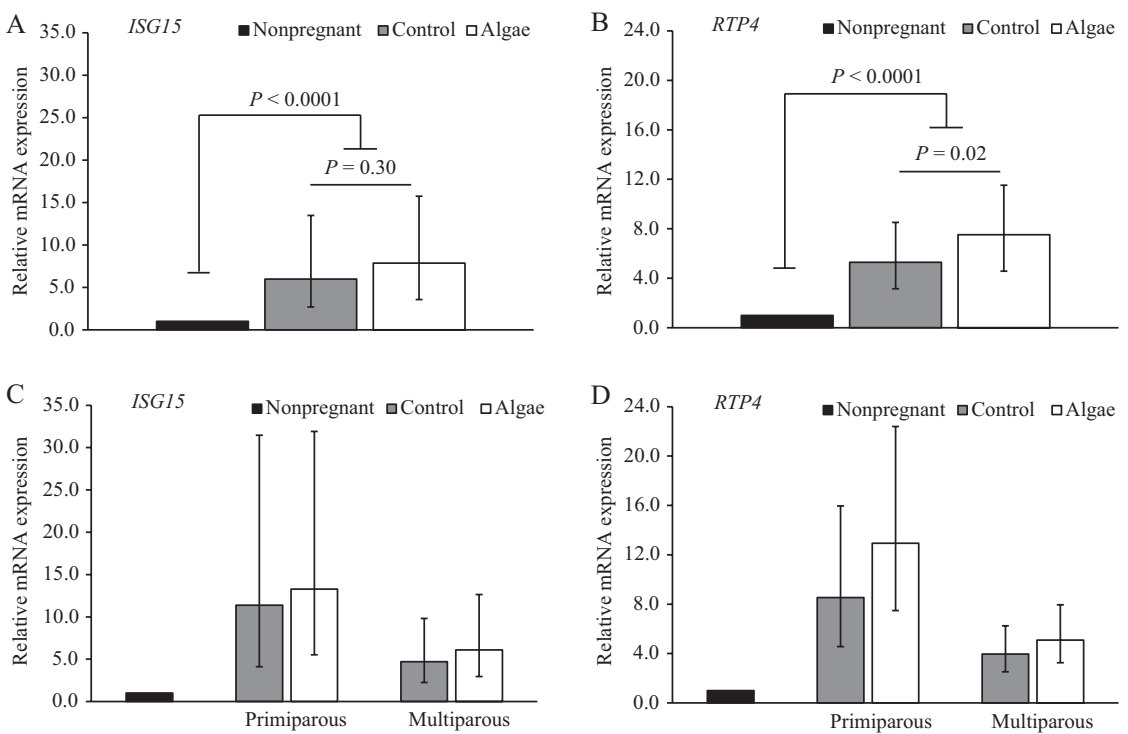

Figure 4 Relative abundance of mRNA for interferon-stimulated genes (ISG) in leukocytes isolated from pregnant cows on day 19 after Al. Cows were fed the same diet as control (gray bars) or Algae (white bars), but Algae-fed cows were supplemented with $100 \mathrm{~g} / \mathrm{cow}$ per day of an algae product rich in docosahexaenoic acid. Nonpregnant cows were the reference group (black bars) for depicting relative mRNA expression. Panel A, ISG15 expression on day 19 after Al according to treatment. Panel B, receptor transporter protein-4 (RTP4) expression on day 19 after $\mathrm{Al}$ according to treatment. Panel C, ISG15 expression on day 19 after Al according to treatment and parity. Panel D, RTP4 expression on day 19 after $\mathrm{Al}$ according to treatment and parity. For ISG15, effects of pregnancy $(P<0.0001)$, treatment $(P=0.30)$, parity $(P=0.03)$ and interaction between treatment and parity $(P=0.92)$. For RTP4, effects of pregnancy $(P<0.0001)$, treatment $(P=0.02)$, parity $(P<0.001)$ and interaction between treatment and parity $(P=0.50)$. The error bars represent the confidence interval $(\mathrm{Cl})$ of normalized expression generated from the lower and upper $95 \% \mathrm{Cl}$ obtained for delta $\mathrm{CT}$ least-squares means differences.

\section{Lactation performance}

Dry matter intake did not differ $(P=0.51)$ between control and Algae treatments averaging 25.5 and $24.8 \pm 0.65 \mathrm{~kg} /$ day respectively. Considering the

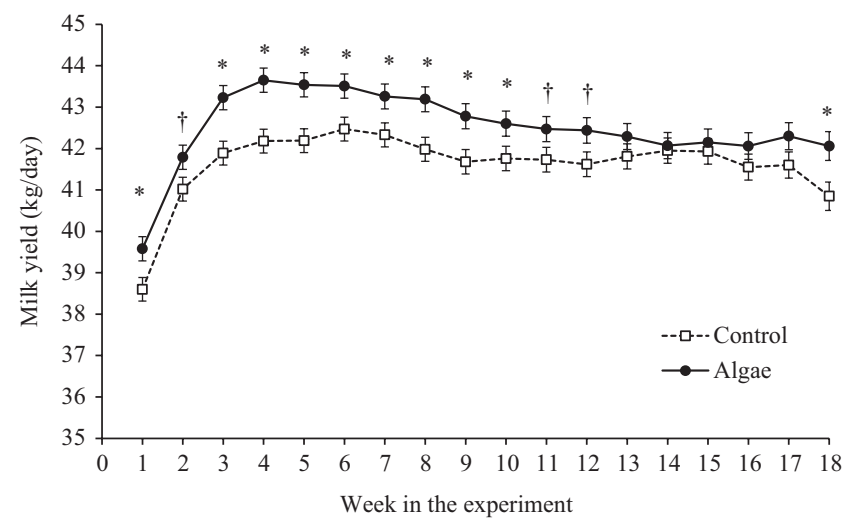

Figure 5 Effect of dietary treatment on milk yield (kg/day) during the experimental period. Cows in control (dotted line, open square) and Algae (solid line, dark circle) were fed the same diet but Algae-fed cows were supplemented with $100 \mathrm{~g} / \mathrm{cow}$ per day of an algae product rich in docosahexaenoic acid. Weekly milk yield ( $\mathrm{kg} /$ day) averages were calculated using data from daily individual measurements. Effects of treatment $(P=0.01)$, parity $(P<0.01)$, week $(P<0.01)$ and interactions between treatment and week $(P<0.01)$ and treatment and parity $(P=0.35)$. Within a week, differences are represented as follows: ${ }^{*} P \leq 0.05 ;{ }^{\dagger} 0.05<P \leq 0.08$. additional $33 \mathrm{~g}$ of supplemental FA provided by $100 \mathrm{~g}$ of Algae, the intake of FA by control and Algae cows did not differ $(P=0.90)$ and averaged $1.046 \pm 0.027$ and $1.051 \pm 0.027 \mathrm{~kg} /$ day respectively. Multiparous cows had greater $(P=0.05)$ dry matter intake than primiparous cows $(26.3$ vs $23.0 \pm 0.63 \mathrm{~kg} /$ day $)$, regardless of treatment. Feeding Algae increased $(P \leq 0.01)$ milk yield by $0.9 \mathrm{~kg} /$ day (Fig. 5) as well as yields of true protein by $20 \mathrm{~g} /$ day, lactose by $50 \mathrm{~g} /$ day and solids-not-fat by $100 \mathrm{~g} /$ day compared with control (Table 5). In contrast, concentration (3.08 vs $3.23 \pm 0.03 \%$ ) and yield of milk fat $(1.30$ vs $1.34 \pm 0.01 \mathrm{~kg} /$ day $)$ decreased $(P<0.02)$ in Algae compared with control cows. No treatment differences were observed for concentrations of true protein, lactose and solids-not-fat in milk. Furthermore, no interaction between treatment and parity were detected for the production variables evaluated. Somatic cell score did not differ with treatments and averaged $1.49 \pm 0.10$. The efficiency of feed conversion into milk yield ( 1.80 vs $1.70 \pm 0.04), 3.5 \%$ fat-corrected milk (1.66 vs $1.61 \pm 0.05)$ and energy-corrected milk (1.65 vs $1.59 \pm 0.05)$ did not differ $(P>0.10)$ between the Algae and the control group.

\section{Fatty acid composition of plasma phospholipids and milk fat}

The FA composition in plasma phospholipids was affected markedly by dietary treatment (Table 6). 
Table 5 Effects of feeding an algae product rich in docosahexaenoic acid on lactation performance in Holstein cows.

\begin{tabular}{|c|c|c|c|c|c|c|c|c|}
\hline \multirow[b]{3}{*}{ Item } & \multicolumn{4}{|c|}{ Treatment $^{\mathrm{a}}$} & \multirow[b]{3}{*}{ S.E.M. } & \multirow{2}{*}{\multicolumn{3}{|c|}{$P$-value ${ }^{b}$}} \\
\hline & \multicolumn{2}{|c|}{ Control } & \multicolumn{2}{|c|}{ Algae } & & & & \\
\hline & Primiparous & Multiparous & Primiparous & Multiparous & & TRT & Parity & TRT $\times$ parity \\
\hline Milk yield (kg/day) & 36.1 & 47.2 & 37.3 & 47.7 & 0.42 & 0.01 & $<0.01$ & 0.35 \\
\hline $3.5 \%$ FCM $^{\mathrm{C}}(\mathrm{kg} /$ day $)$ & 35.1 & 44.4 & 35.5 & 43.6 & 0.42 & 0.54 & $<0.01$ & 0.11 \\
\hline $\mathrm{ECM}^{\mathrm{d}}(\mathrm{kg} /$ day $)$ & 34.6 & 43.7 & 35.1 & 43.2 & 0.39 & 0.97 & $<0.01$ & 0.13 \\
\hline \multicolumn{9}{|l|}{ Fat } \\
\hline$\%$ & 3.32 & 3.13 & 3.17 & 2.98 & 0.05 & $<0.01$ & $<0.01$ & 0.85 \\
\hline Yield (kg/day) & 1.20 & 1.47 & 1.19 & 1.41 & 0.02 & 0.03 & $<0.01$ & 0.15 \\
\hline \multicolumn{9}{|l|}{ True protein } \\
\hline$\%$ & 2.91 & 2.83 & 2.93 & 2.84 & 0.02 & 0.76 & $<0.01$ & 0.78 \\
\hline Yield (kg/day) & 1.06 & 1.33 & 1.09 & 1.35 & 0.01 & $<0.01$ & $<0.01$ & 0.39 \\
\hline \multicolumn{9}{|l|}{ Lactose } \\
\hline$\%$ & 4.95 & 4.75 & 4.94 & 4.76 & 0.01 & 0.73 & $<0.01$ & 0.84 \\
\hline Yield (kg/day) & 1.79 & 2.24 & 1.86 & 2.28 & 0.02 & 0.01 & $<0.01$ & 0.36 \\
\hline \multicolumn{9}{|l|}{ Solids not fat } \\
\hline$\%$ & 8.75 & 8.43 & 8.76 & 8.47 & 0.03 & 0.78 & $<0.01$ & 0.47 \\
\hline Yield (kg/day) & 3.17 & 3.97 & 3.29 & 4.06 & 0.03 & $<0.01$ & $<0.01$ & 0.46 \\
\hline SCSe & 1.38 & 1.60 & 1.35 & 1.63 & 0.17 & 0.99 & 0.07 & 0.85 \\
\hline
\end{tabular}

${ }^{a}$ Cows in control and Algae were fed the same diet but Algae was supplemented with $100 \mathrm{~g} / \mathrm{cow}$ per day of an algae product rich in docosahexaenoic acid. ${ }^{\text {bTRT }}=$ effect of treatment (control vs Algae); parity=effect of parity (primiparous vs multiparous);

TRT $\times$ parity $=$ interaction between TRT and parity. ${ }^{\mathrm{c}} 3.5 \%$ fat-corrected milk $=((0.4324 \times$ milk $\mathrm{kg})+(16.218 \times$ fat yield $\mathrm{kg}))$. ${ }^{\mathrm{d}}$ Energy corrected milk $=((0.3246 \times$ milk kg $)+(12.86 \times$ fat yield kg $)+(7.04 \times$ protein yield $\mathrm{kg}))$. eSomatic cell score $=\log _{10}(\mathrm{SCC} / 12.5) / \log _{10} 2$.

Feeding Algae increased $(P \leq 0.04)$ concentrations of total $\mathrm{n}-3$ and polyunsaturated $\mathrm{FA}$, and the individual FA palmitic acid, vaccenic acid, linoleic acid, CLA cis-9 trans-11 and trans-10 cis-12 and DHA, whereas eicosapentaenoic acid tended $(P=0.06)$ to increase with feeding Algae compared with control. Moreover, cows fed Algae had reduced $(P<0.01)$ concentrations of oleic acid, total monounsaturated FA, gamma-linolenic acid and arachidonic acid in the phospholipid fraction of plasma. When FA in phospholipids were calculated per $\mathrm{mL}$ of plasma, a similar pattern to that of the FA profile in phospholipids was also observed (Table 7). Feeding Algae resulted in enriched $(P<0.01)$ concentrations in plasma of total $n-3 F A$, and the individual $F A$ vaccenic acid, CLA trans-10 cis-12 and DHA, whereas CLA cis-9 trans-11 tended $(P=0.08)$ to increase with feeding Algae compared with control. In addition, cows fed Algae had reduced $(P \leq 0.04)$ concentrations in plasma

Table 6 Effects of feeding an algae product rich in docosahexaenoic acid on fatty acid composition of phospholipid fraction of plasma from Holstein cows $(n=50)$.

\begin{tabular}{|c|c|c|c|c|c|c|}
\hline \multirow[b]{2}{*}{ Fatty acid, $\mathrm{g} / 100 \mathrm{~g}$ of fatty acids } & \multicolumn{2}{|c|}{ Treatment $^{\mathrm{a}}$} & \multirow[b]{2}{*}{ S.E.M. } & \multicolumn{3}{|c|}{$P$ value $^{b}$} \\
\hline & Control & Algae & & TRT & Parity & TRT $\times$ parity \\
\hline C16:0 & 14.10 & 15.87 & 0.28 & $<0.01$ & 0.11 & 0.82 \\
\hline C18:0 & 24.03 & 23.56 & 0.35 & 0.35 & 0.26 & 0.44 \\
\hline C18:1 cis-9 & 9.615 & 8.008 & 0.227 & $<0.01$ & 0.83 & 0.89 \\
\hline C18:1 trans- 11 & 0.481 & 0.774 & 0.044 & $<0.01$ & 0.08 & 0.17 \\
\hline C18:2 cis-9, cis-12 & 31.57 & 33.20 & 0.35 & $<0.01$ & 0.60 & 0.81 \\
\hline C18:3 cis-9, cis-12, cis-15 & 1.024 & 1.034 & 0.043 & 0.87 & 0.77 & 0.51 \\
\hline C18:3 cis-6, cis-9, cis-12 & 0.241 & 0.110 & 0.011 & $<0.01$ & 0.95 & 0.38 \\
\hline $\mathrm{CLA}^{3}$ cis-9, trans- 11 & 0.098 & 0.113 & 0.005 & 0.04 & 0.75 & 0.85 \\
\hline CLA trans-10, cis-12 & 0.010 & 0.030 & 0.004 & $<0.01$ & 0.47 & 0.80 \\
\hline C20:4 cis-5, cis-8, cis- 11, cis- 14 & 2.584 & 1.610 & 0.119 & $<0.01$ & 0.79 & 0.15 \\
\hline C20:5 cis-5, cis-8, cis-11, cis-14, cis-17 & 0.308 & 0.373 & 0.025 & 0.06 & 0.74 & 0.20 \\
\hline C22:6 cis-4, cis-7, cis-10, cis-13, cis-16, cis-19 & 0.065 & 2.160 & 0.136 & $<0.01$ & 0.42 & 0.34 \\
\hline \multicolumn{7}{|l|}{ Sum of fatty acids } \\
\hline Saturated & 43.99 & 43.17 & 0.35 & 0.11 & 0.86 & 0.36 \\
\hline Monounsaturated & 14.44 & 12.65 & 0.26 & $<0.01$ & 0.66 & 0.63 \\
\hline Polyunsaturated & 37.57 & 39.54 & 0.42 & $<0.01$ & 0.72 & 0.19 \\
\hline$n-6$ & 35.24 & 35.54 & 0.32 & 0.51 & 0.68 & 0.35 \\
\hline$n-3$ & 2.243 & 3.981 & 0.205 & $<0.01$ & 0.86 & 0.21 \\
\hline
\end{tabular}

${ }^{a}$ Cows in control and Algae were fed the same diet but Algae was supplemented with $100 \mathrm{~g} / \mathrm{cow}$ per day of an algae product rich in docosahexaenoic acid. ${ }^{~}$ TRT = effect of treatment (control vs Algae); parity= effect of parity (primiparous vs multiparous);

TRT $\times$ parity $=$ interaction between treatment and parity. ${ }^{c} \mathrm{CLA}$, conjugated linoleic acid. 
Table 7 Effects of feeding an algae product rich in docosahexaenoic acid on fatty acid content present in the phospholipid fraction of plasma from Holstein cows $(n=50)$.

\begin{tabular}{|c|c|c|c|c|c|c|}
\hline \multirow[b]{2}{*}{ Fatty acid, $\mu \mathrm{g}$ of $\mathrm{FA} / \mathrm{mL}$ of plasma } & \multicolumn{2}{|c|}{ Treatment $^{\mathrm{a}}$} & \multirow[b]{2}{*}{ S.E.M. } & \multicolumn{3}{|c|}{$P$ value ${ }^{b}$} \\
\hline & Control & Algae & & TRT & Parity & TRT $\times$ parity \\
\hline C16:0 & 128.2 & 143.8 & 6.53 & 0.10 & 0.20 & 0.67 \\
\hline C18:0 & 221.8 & 213.9 & 11.4 & 0.63 & 0.64 & 0.82 \\
\hline C18:1 cis-9 & 87.74 & 72.29 & 4.01 & $<0.01$ & 0.68 & 0.69 \\
\hline C18:1 trans-11 & 4.443 & 7.070 & 0.50 & $<0.01$ & 0.30 & 0.34 \\
\hline C18:2 cis-9, cis-12 & 291.1 & 301.1 & 15.0 & 0.64 & 0.36 & 0.90 \\
\hline C18:3 cis-9, cis-12, cis-15 & 9.446 & 9.300 & 0.59 & 0.86 & 0.38 & 0.55 \\
\hline C18:3 cis-6, cis-9, cis-12 & 2.225 & 0.997 & 0.136 & $<0.01$ & 0.90 & 0.51 \\
\hline $\mathrm{CLA}^{3}$ cis -9 , trans -11 & 0.882 & 1.026 & 0.058 & 0.08 & 0.55 & 0.91 \\
\hline CLA trans-10, cis-12 & 0.099 & 0.227 & 0.043 & $<0.01$ & 0.34 & 0.90 \\
\hline C20:4 cis-5, cis-8, cis- 11 , cis- 14 & 23.48 & 14.45 & 1.385 & $<0.01$ & 0.90 & 0.16 \\
\hline C20:5 cis-5, cis-8, cis-11, cis-14, cis-17 & 2.831 & 3.313 & 0.261 & 0.20 & 0.81 & 0.13 \\
\hline C22:6 cis-4, cis-7, cis-10, cis-13, cis-16, cis-19 & 0.576 & 19.34 & 1.382 & $<0.01$ & 0.23 & 0.18 \\
\hline \multicolumn{7}{|l|}{ Sum of fatty acids } \\
\hline Saturated & 403.8 & 391.8 & 19.9 & 0.67 & 0.43 & 0.95 \\
\hline Monounsaturated & 132.2 & 114.0 & 6.05 & 0.04 & 0.65 & 0.82 \\
\hline Polyunsaturated & 345.9 & 358.0 & 17.6 & 0.63 & 0.38 & 0.66 \\
\hline$n-6$ & 324.6 & 322.1 & 16.3 & 0.91 & 0.38 & 0.79 \\
\hline$n-3$ & 20.57 & 35.68 & 2.27 & $<0.01$ & 0.46 & 0.15 \\
\hline
\end{tabular}

${ }^{\mathrm{a} C o w s}$ in control and Algae were fed the same diet but Algae was supplemented with $100 \mathrm{~g} / \mathrm{cow}$ per day of an algae product rich in docosahexaenoic acid. ${ }^{\mathrm{T} T R T}=$ effect of treatment (control vs Algae); parity= effect of parity (primiparous vs multiparous);

TRT $\times$ parity $=$ interaction between treatment and parity. ${ }^{c} \mathrm{CLA}$, conjugated linoleic acid.

of oleic acid, total monounsaturated FA, gammalinolenic acid and arachidonic acid present in the phospholipid fraction.

As observed for the FA profile in plasma phospholipids, the FA composition of milk fat also was affected drastically by treatment (Table 8). Cows fed Algae had milk fat with reduced $(P<0.01)$ concentrations of total de novo synthesized, preformed and saturated FA. However, feeding Algae increased $(P \leq 0.05)$ concentrations of total n-6, n-3 and polyunsaturated FA,

Table 8 Effects of feeding an algae product rich in docosahexaenoic acid on the fatty acid composition of milk fat in Holstein cows ( $n=50)$.

\begin{tabular}{|c|c|c|c|c|c|c|}
\hline \multirow[b]{2}{*}{ Fatty acid, g/100g fatty acids } & \multicolumn{2}{|c|}{ Treatment $^{\mathrm{a}}$} & \multirow[b]{2}{*}{ S.E.M. } & \multicolumn{3}{|c|}{$P$ value $^{b}$} \\
\hline & Control & Algae & & TRT & Parity & TRT $\times$ parity \\
\hline \multicolumn{7}{|l|}{ Summation by source ${ }^{c}$} \\
\hline De novo & 21.77 & 19.78 & 0.45 & $<0.01$ & 0.02 & 0.25 \\
\hline Mixed & 45.38 & 49.43 & 0.72 & $<0.01$ & 0.03 & 0.14 \\
\hline Preformed & 32.83 & 30.78 & 0.50 & $<0.01$ & 0.35 & 0.28 \\
\hline \multicolumn{7}{|l|}{ Selected individual fatty acids } \\
\hline C16:0 & 31.39 & 29.29 & 0.47 & $<0.01$ & 0.45 & 0.25 \\
\hline C18:0 & 11.04 & 11.60 & 0.38 & 0.30 & 0.15 & 0.22 \\
\hline C18:1 cis-9 & 20.44 & 21.54 & 0.40 & 0.06 & 0.18 & 0.18 \\
\hline C18:1 trans-11 & 0.843 & 1.218 & 0.060 & $<0.01$ & 0.04 & 0.62 \\
\hline C18:2 cis-9, cis-12 & 2.450 & 2.716 & 0.060 & $<0.01$ & 0.89 & 0.62 \\
\hline C18:3 cis-9, cis- 12 , cis-15 & 0.273 & 0.318 & 0.007 & $<0.01$ & 0.15 & 0.66 \\
\hline CLA $^{\mathrm{d}}$ cis- 9, trans -11 & 0.389 & 0.549 & 0.023 & $<0.01$ & 0.05 & 0.37 \\
\hline CLA trans-9, cis-11 & 0.007 & 0.016 & 0.002 & $<0.01$ & 0.67 & 0.79 \\
\hline CLA trans- 10, cis -12 & 0.007 & 0.015 & 0.003 & 0.05 & 0.97 & 0.55 \\
\hline C20:5 cis-5, cis-8, cis-11, cis-14, cis-17 & 0.022 & 0.028 & 0.001 & $<0.01$ & 0.48 & 0.07 \\
\hline C22:6 cis-4, cis-7, cis-10, cis-13, cis-16, cis-19 & 0.002 & 0.242 & 0.010 & $<0.01$ & 0.17 & 0.12 \\
\hline \multicolumn{7}{|l|}{ Sum of fatty acids } \\
\hline Saturated & 65.90 & 62.06 & 0.67 & $<0.01$ & 0.19 & 0.32 \\
\hline Monounsaturated & 25.17 & 26.39 & 0.43 & 0.05 & 0.30 & 0.15 \\
\hline Polyunsaturated & 3.167 & 3.630 & 0.069 & $<0.01$ & 0.39 & 0.99 \\
\hline$n-6$ & 2.655 & 2.880 & 0.062 & 0.01 & 0.74 & 0.75 \\
\hline $\mathrm{n}-3$ & 0.512 & 0.751 & 0.015 & $<0.01$ & 0.01 & 0.17 \\
\hline
\end{tabular}

${ }^{\mathrm{a} C o w s}$ in control and Algae were fed the same diet but Algae was supplemented with $100 \mathrm{~g} / \mathrm{cow}$ per day of an algae product rich in docosahexaenoic acid. ${ }^{\mathrm{b}} \mathrm{TRT}=$ effect of treatment (control vs Algae); parity = effect of parity (primiparous vs multiparous);

TRT $\times$ parity $=$ interaction between treatment and parity. ${ }^{\circ}$ De novo FA originate from mammary de novo synthesis $(<16$ carbons); preformed FA originate from the diet or are mobilized from plasma pool or adipose depots (>16 carbons), and mixed FA originate from both sources. ${ }^{\mathrm{d} C L A}$, conjugated linoleic acid. 
and individual FA linoleic acid, $\alpha$-linolenic acid, CLA trans-10 cis-12 and eicosapentaenoic acid compared with control cows. In addition, the milk fat of cows fed Algae had increased $(P<0.01)$ incorporation of DHA compared with control-fed cows. Furthermore, an interaction $(P=0.07)$ between treatment and parity was observed for eicosapentaenoic acid in milk fat, because incorporation of this FA milk fat of primiparous cows fed Algae was greater $(P<0.01)$ than their counterparts fed control (control $=0.021$ vs Algae $=0.030 \pm 0.002 \mathrm{~g} / 100 \mathrm{~g}$ FA), whereas for multiparous cows, feeding Algae only tended $(P=0.07)$ to increase in eicosapentaenoic acid in milk fat (control $=0.023$ vs Algae $=0.026 \pm 0.001 \mathrm{~g} / 100 \mathrm{~g}$ of FA).

\section{Discussion}

Daily dietary supplementation with algae rich in DHA resulted in increased proportion of estrous cyclicity and pregnancy at the first $\mathrm{Al}$ in primiparous cows and increased the overall $\mathrm{P} / \mathrm{Al}$ and reduced days to pregnancy in all cows. In addition, the normalized expression of the interferon-stimulated gene RTP4, which is associated with the amount of interferon-tau secreted by the conceptus, was upregulated in peripheral blood leukocytes of pregnant cows fed Algae compared with pregnant control cows. Feeding Algae altered the profile of FA in plasma phospholipids and milk fat, resulting in increased incorporation of n-3 FA in those lipid fractions and reduced concentrations of arachidonic acid and gamma-linolenic acid in phospholipids from plasma. Furthermore, cows fed Algae produced $0.9 \mathrm{~kg} /$ day more milk, 30g/day more milk true protein and $100 \mathrm{~g}$ more solids-not-fat than control cows. However, yield of milk fat decreased 30 g/day and energy-corrected milk remained unchanged with feeding of Algae.

Supplementation with Algae was initiated past the period when cows have extensive lipomobilization and feed intake is low, which makes it more challenging to alter tissue lipid profiles. Also, previous research showed that supplementing $\mathrm{n}-3$ FA starting at 30 days postpartum was beneficial to embryo survival (Silvestre et al. 2011a). It is important to note that cows were supplemented with a small amount of n-3 FA, $10.2 \mathrm{~g}$ /day, because feeding large quantities of polyunsaturated FA to early lactation cows can increase tissue peroxidation and elicit more oxidative stress (Gobert et al. 2009, Wullepit et al. 2012). Such negative effects of n-3 FA might be exacerbated if large quantities are fed during the transition period, when lipomobilization is already extensive (Wullepit et al. 2012). On the other hand, at low amounts, n-3 FA acts as anti- rather than pro-oxidant in endothelial vascular cells and placental tissues by reducing inflammation and reducing the formation of reactive oxygen species (Jones et al. 2013, Giordano \& Visioli 2014). Although the Algae product contained several FAs, other non-FA lipids, carbohydrates and protein, the only identified compound fed in appreciable amounts sufficient to influence dairy cow fertility was DHA. The provision of $16 \mathrm{~g} /$ day of palmitic acid is unlikely to have any impact on reproduction, other than supplying a small quantity of calories. The other polyunsaturated FA, docosapentaenoic acid (C22:5 n-6), was supplemented in small quantity and only a marginal increase was observed in plasma phospholipids with no increase in milk fat, whereas DHA increased 33-fold in plasma phospholipids and in milk fat in cows fed Algae. The amounts of crude protein and carbohydrates were insufficient to alter the intake of those compounds by cows. Therefore, although we did not have pure source of a single FA, we suggest that the animal responses observed in the current experiment are attributed primarily to DHA given the expressive tissue incorporation and the known biological effects of this FA.

It is well established that fat supplementation in diets of lactating dairy cows often benefits reproduction. A recent meta-analysis of the literature included 17 experiments with 26 comparisons reported a $27 \%$ increase in the relative risk of pregnancy, and the results showed little heterogeneity suggesting that responses were consistent across different fat sources and conditions evaluated (Rodney et al. 2015). Nevertheless, it is also known that different FAs have distinct effects on cellular functions and gene expression (Wahle et al. 2003), including differential impacts on tissues of the reproductive tract (Bilby et al. 2006a,b, Zachut et al. 2008). Therefore, it is not surprising that different FAs might have distinct effects on fertility responses of dairy cows (Santos et al. 2008, Silvestre et al. 2011a). Feeding n-3 FA promotes changes in the FA composition of reproductive tissues that can alter cell membrane fluidity and gene expression, which might favor the establishment and maintenance of pregnancy in dairy cattle (Santos et al. 2008). Indeed, feeding Algae rich in DHA increased the incorporation of polyunsaturated FA into milk fat and plasma phospholipids and improved both P/AI and pregnancy rate. In agreement, Silvestre and coworkers (Silvestre et al. 2011a,b) showed that feeding Ca salts containing fish oil FA, which were rich in DHA and eicosapentaenoic acid, increased the incorporation of those FA into maternal tissues and improved P/AI by reducing pregnancy loss. Others have also shown that feeding n-3 FA improved P/Al (Petit et al. 2001) and reduced pregnancy loss in dairy cows (Ambrose et al. 2006).

Feeding Algae increased the concentrations of DHA and other n-3 FA and reduced arachidonic acid and gamma-linolenic acid in plasma phospholipids, thereby confirming that those FA were absorbed and transferred to the plasma pool becoming available for use by all body tissues. It is important to mention that feeding Algae not only altered the relative concentrations of FA in plasma phospholipids but similar changes were also 
observed when the absolute concentrations of those FA were analyzed. Thus, the availability of specific FA was altered by the dietary treatment imposed, which likely not only influenced plasma phospholipid and milk FA composition but also the composition of FA in other tissues. The transfer efficiency of n-3 FA into bovine tissues is low, and only $5-7 \%$ of eicosapentaenoic acid and DHA fed appear in milk fat (Mattos et al. 2004). However, feeding fish oil FA consistently increased the incorporation of eicosapentaenoic acid and DHA in placentomes, immune cells, endometrial cells, liver, follicular fluid and in conceptuses (Bilby et al. 2006a, Moussavi et al. 2007a, Childs et al. 2008, Silvestre et al. 2011b, Greco et al. 2014). Strong positive relationships between plasma and uterine endometrial concentrations of eicosapentaenoic acid $\left(r^{2}=0.86\right)$ and total n-3 FA $\left(r^{2}=0.77\right)$ have been reported in beef heifers (Childs et al. 2008). Based on the changes in phospholipid FA in the plasma pool, it is likely probable that cows fed Algae had reduced concentrations of arachidonic acid and gamma-linolenic acid in phospholipid pools of the endometrium, which limits the amount of these precursors for production of the series 2 prostaglandins in the uterus. Feeding fish oil FA increased the incorporation of n-3 FA in the endometrial tissue, altered the expression of genes involved in the luteolytic cascade and attenuated the spontaneous release of $\mathrm{PGF}_{2 \alpha}$ in lactating dairy cows (Greco et al. 2014). Also, feeding Algae likely increased the incorporation of DHA and other n-3 FA in the endometrium of dairy cows, which might favor pregnancy by either influencing embryonic development or altering the synthesis of PGF $_{2 \alpha}$ (Mattos et al. 2004, Greco et al. 2014).

Feeding n-3 FA to dairy cows increased tissue content of those FA and attenuated the proinflammatory response in vivo and in vitro (Silvestre et al. 2011b, Greco et al. 2015). Eicosapentaenoic and DHA influence the expression of genes involved in the luteolytic cascade in dairy cows (Bilby et al. 2006a, Greco et al. 2014), although pulses are attenuated (Mattos et al. 2003), the secretion of $\mathrm{PGF}_{2 \alpha}$ is not abolished, and prostaglandins are essential for proper embryo development and maintenance of pregnancy in ruminants (Dorniak et al. 2011). It is possible that improvements in reproduction observed with feeding n-3 FA might be mediated by changes in immune and inflammatory responses. Inflammatory diseases in the early lactation reduces $\mathrm{P} / \mathrm{Al}$ and increases the risk of pregnancy loss, and conceptuses derived from cows that had disease have increased the expression of proinflammatory genes and genes responsible for antigen presentation, suggesting a potential for increased fetal antigen presentation to the surveilling maternal immune system (Ribeiro et al. 2016c). Because n-3 FA such as DHA can attenuate inflammation and innate immune responses in vivo and in vitro (Silvestre et al. 2011b, Greco et al. 2015), it is plausible to postulate that improvements in P/AI or maintenance of pregnancy in dairy cattle fed $n-3$ FA might have been mediated by attenuation of the maternal immune system to favor the establishment and maintenance of pregnancy in dairy cows (Santos et al. 2008, Silvestre et al. 2011a, Ribeiro et al. 2016a). Also, FA and lipid derivatives are essential for conceptus development in the bovine. During early gestation, remarkable changes in the expression of genes related to FA and lipid metabolism occur as the conceptus develops from the ovoid to the elongated stage at around day 16 of gestation (Ribeiro et al. 2016b). The bovine conceptus takes up FA from the surrounding environment and incorporates those lipids into tissues for synthesis of phospholipids or for energy generation (Ribeiro et al. 2016a). In fact, expression of genes related to lipid uptake, FA biosynthesis and modification of FA increase substantially during the onset of conceptus elongation in dairy cattle (Ribeiro et al. 2016b). Some polyunsaturated FA such as DHA and other n-3 FA are natural ligands of transcription factors essential for conceptus elongation. One such transcription factor is peroxisome-proliferator activator receptor gamma (PPARG), which is a highly expressed gene in bovine conceptus during elongation (Ribeiro et al. 2016b), and loss of function of PPARG gene in utero resulted in growth retardation in ovine embryos (Brooks et al. 2015).

The mRNA expression of one of the two interferonstimulated genes investigated in maternal peripheral blood leukocytes increased in pregnant cows fed Algae compared with pregnant cows fed the control diet. During early pregnancy, trophoblast cells produce interferon-tau, which is responsible for the servomechanism for the maintenance of pregnancy during early gestation by blocking the luteolytic cascade and endometrial pulses of $\mathrm{PGF}_{2 \alpha}$. Interferon-tau produced by the conceptus reaches the maternal circulation exposing maternal peripheral cells to this protein (Oliveira et al. 2008), which might have implications for the maintenance of pregnancy in cattle. Interferontau in the maternal circulation influences immune cells, and expression of interferon-stimulated genes in peripheral blood cells was correlated positively to the amount of interferon-tau produced by the trophoblast (Matsuyama et al. 2012), which suggests that greater expression of these genes in leukocytes indicate a more advanced conceptus (Ribeiro et al. 2014). The increase in mRNA for RTP4 in leukocytes of Algae cows suggests that day 19 conceptuses were more advanced and produced greater amounts of interferon-tau, a possible mechanism for improved P/AI observed with feeding $\mathrm{n}-3 \mathrm{FA}$ in the current experiment.

The gene RTP4 and its protein are expressed in a multitude of reproductive tissues (Gifford et al. 2008), in addition to leukocytes, and massive increments in mRNA expression are detected during early pregnancy in response to interferon-tau. RTP4 is a gene originally identified in olfactory neurons, but pregnant ewes express 
RTP4 mRNA localized in different cell layers of the glandular endometrium, and expression was upregulated in response to pregnancy (Gifford et al. 2008). Indeed, both pregnant ewes and heifers express RTP4 mRNA and protein in endometrial luminal epithelium, glandular epithelium, stroma, corpus luteum and in granulosa cells (Gifford et al. 2008, Horsley et al2016, Wilson etal. 2016). Because RTP4 is a class of G-protein-coupled receptor transporters, it is plausible to speculate that expression of these proteins in the endometrium might influence chemokine receptors involved in the attachment of the trophoblast and subsequent invasion during the periimplantation period and/or lymphocyte recruitment such as $\mathrm{T}$ regulatory cells important for promoting the tolerance to paternal alloantigens expressed in the conceptus. The differences in expression of RTP4 in pregnant cows fed Algae compared with control cows were observed in spite of similar concentrations of progesterone after AI. Progesterone is known to stimulate histotroph secretion that increases trophoblast elongation and proliferation. The lack of difference in progesterone concentrations between treatments suggests that benefits of supplementing DHA on interferon-stimulated gene expression were likely a direct effect of FA on embryo development and not an indirect action of distinct concentrations of progesterone. However, the possibility that DHA might have sensitized blood leukocytes to respond to conceptus-derived interferon-tau cannot be ignored.

In a functional analysis of the transcriptome of day 16 bovine conceptuses, FA and PPARG were placed as upstream regulators of changes in gene expression during conceptus elongation (Ribeiro et al. 2016b). Peroxisome-proliferator-activated receptor gamma is known to regulate immune cell function and plasticity, particularly the differentiation of $\mathrm{T}$ helper lymphocytes to regulatory $\mathrm{T}$ cells, which have been described as the main cell type-controlling immune responses in the endometrium, avoiding rejection of the conceptus by the maternal immune system (Samstein et al. 2012). Expression of PPARG in conceptus cells was highly correlated with length of the conceptus and concentration of interferon-tau in the uterine flushing collected from pregnant cows (Ribeiro et al. 2016b). This biological association infers that conceptus elongation is mediated, in part, by the activation of PPARG, which stimulates trophoblast elongation and proliferation in dairy cattle. Activation of PPARG signaling is important for placental development, immunomodulation and stimulation of conceptus elongation. It is possible that feeding $\mathrm{DHA}$ stimulated such pathways to improve P/AI in dairy cows observed in the current experiment. In cell culture, DHA stimulates angiogenesis in placental trophoblast cell lines by increasing mRNA expression of angiogenic genes such as angiopoietin-like 4 (ANGPTL4) and vascular endothelial growth factor (VEGF; (Johnsen et al. 2011), which is important for normal placentation.
The benefits of improving fertility when cows were fed Algae, however, were more pronounced in primiparous than that in multiparous cows. A greater proportion of primiparous cows fed Algae resumed ovulation by 58 days postpartum compared with primiparous control cows. In agreement, Jahani-Moghadam and coworkers (Jahani-Moghadam et al. 2015) reported that dairy cows supplemented with linseed, which is rich in n-3 FA, had earlier resumption of estrous cyclicity compared with cows fed a diet supplemented with $\mathrm{Ca}$ salts of palm oil FA distillate, which contains mostly saturated and monounsaturated FA. It is well accepted that cows that have resumed estrous cyclicity by the end of the voluntary waiting period at approximately 60 days postpartum have improved reproductive performance compared with cows that remain anovular by the same time postpartum (Ribeiro et al. 2016c). This may explain partially the improved P/Al and reduced days to pregnancy in primiparous cows fed Algae. The exact reason why a greater proportion of primiparous cows fed Algae were estrous cyclic is not fully understood. Estrous cyclicity by 58 days postpartum was not altered by treatment in multiparous cows. It is possible that the amount of supplemental FA supplied to multiparous cows was not sufficient to promote these benefits in the beginning of the breeding period, and longer feeding was needed in cows that have larger body size and greater milk yield. Also, it is possible that a longer period of feeding might be needed for multiparous cows to elicit the benefits on fertility. A tendency for increased rate of pregnancy was observed in multiparous cows when fed Algae, but the response was observed after approximately 85 days postpartum, when they had received the treatments for at least 60 days. Because multiparous cows are larger animals and have greater milk secretion of FA, it is plausible to suggest that a longer feeding period or a larger quantity of DHA might be needed for tissue accumulation of specific FA to elicit the same response in fertility as those observed in primiparous cows. Although the benefit of Algae was more pronounced in primiparous cows, after 120 days of treatments, feeding Algae increased P/AI and reduced days to pregnancy in both multiparous and primiparous cows.

Feeding fat often influences pre-ovulatory follicle diameter and concentrations of progesterone in blood of dairy cows (Santos et al. 2008); however, the type of FA fed usually has minor effects on those responses, including n-3 FA (Moussavi et al. 2007a). Because the intake of total FA by cows in the current experiment did not differ between treatments, it is not surprising that pre-ovulatory follicle diameter and progesterone concentrations before and after insemination remained unaltered by dietary treatments.

Pregnant primiparous cows had greater mRNA expression of interferon-stimulated genes in maternal leukocytes, regardless of the diet assigned. Green and coworkers (Green et al. 2010) also reported 
greater expression of interferon-stimulated genes in primiparous cows than that in multiparous cows. Likely, the concentration of interferon-tau in the maternal circulation was greater in primiparous cows than that in multiparous cows either because primiparous cows had larger conceptuses or because of their smaller body size and less body weight or a combination of both.

Concentrations of insulin and IGF-1 in plasma were modestly affected by dietary treatments. Algae cows not receiving bST had the lowest concentrations of insulin in the current study. Others have shown that feeding fish oil FA, which contains DHA, reduced concentrations of insulin in blood of dairy cows (Bilby et al. 2006b), although this response is not consistent (Moussavi et al. 2007b). In cases when dry matter intake increased with feeding n-3 FA as Ca salts of fish oil, then concentrations of insulin in blood also increased in early lactation dairy cows (Moussavi et al. 2007b). It is well accepted that concentrations of insulin reflect the availability of glucose that stimulates pancreatic beta cells to produce and release insulin. Fatty acids of the n-3 family usually have insulinotropic activity in monogastrics stimulating insulin release and tissue sensitivity to insulin (Bhaswanta et al. 2015). Nevertheless, in dairy cattle, supplementing FA to the diet usually reduces concentrations of insulin, except when total caloric intake increased with fat feeding (Staples et al. 1998). When cows received bST, those fed Algae had greater concentrations of IGF-1 than control cows. Somatotropin stimulates hepatic IGF-1 production and the greater concentrations in cows fed Algae suggest that response to bST might have been enhanced by feeding n-3 FA. In monogastrics, the insulinotropic and anti-inflammatory effects of n-3 FA usually enhance hepatic IGF-1 secretion and tissue sensitivity to IGF-1 (Bhaswanta et al. 2015).

Elevated basal plasma concentrations of IGF-1 were observed in cyclic cows fed with n-3 from fish oil compared with cows fed a control isolipidic diet lacking DHA and eicosapentaenoic acid. However, in response to bST, n-3-fed cows had increased GH and reduced IGF-1 plasma concentrations compared with controlfed cows (Bilby et al. 2006b). Thus, it appears that n-3 may be modulating the GH-IGF-1 system. Likewise, feeding n-3 FA as Ca salts of fish oil tended to increase the concentrations of IGF- 1 in early lactation dairy cows compared with cows fed Ca salts of palm oil distillate FA (Moussavi et al. 2007b). Because cows fed n-3 FA also had greater dry matter intake and insulin concentrations in Moussavi and coworkers (Moussavi et al. 2007b), it is possible that the IGF-1 response reflected the improved energy status and earlier recoupling of the somatotropic axis. Additional experiments need to confirm if supplementing cows with DHA influence the IGF-1 response to bST.

Supplementation with Algae had no impact on dry matter intake, but increased yields of milk, true protein and lactose compared with cows fed the control diet. The increases in yields of milk components were caused by the greater milk yield. Nevertheless, the concentration and yield of milk fat decreased in cows fed Algae compared with control cows. Collectively, these responses resulted in the same yields of $3.5 \%$ fatcorrected milk and energy-corrected milk. Lactation responses to feeding n-3 FA depend upon the amounts offered and the interactions with other dietary components. Large quantities supplemented to diets that are low in forage can depress dry matter intake and negatively influence lactation performance. Hostens and coworkers (Hostens et al. 2011) offered dairy cows $2 \mathrm{~kg}$ of a supplement containing $44 \mathrm{~g}$ of $\mathrm{DHA}$ and reported an increase in milk yield, but an abrupt decrease in concentration and yield of milk fat. Although cows in the current experiment experienced a depression in milk fat yield when fed Algae, the total energy output as milk remained similar to that of control cows. Feeding polyunsaturated FA may favor the accumulation of numerous mono and dienoic trans-isomers of C18 FA in the rumen. Some of these intermediates (e.g., CLA trans10 cis-12 and trans- 9 cis-11) are known to promote milk fat depression by the downregulation of key lipogenic genes in the mammary gland (Bauman et al. 2011). Indeed, feeding Algae increased the aforementioned CLA in milk fat, which likely caused the observed depression in milk fat yield. Cows fed Algae had reduced concentrations of de novo-synthesized FA, which were replaced by preformed FA originating from the diet or from storage pools.

Feeding the Algae supplement to supply $10 \mathrm{~g}$ of DHA per cow per day improved reproductive performance in dairy cows. A greater proportion of primiparous cows fed Algae were estrous cyclic by 58 days postpartum compared with primiparous control cows, which resulted in an increased proportion of Algae cows detected in estrus before the first postpartum Al. Feeding algae improved P/ $\mathrm{Al}$ at first $\mathrm{Al}$ in primiparous cows and at all Als performed in the 120-days treatment period in both primiparous and multiparous cows. The increased P/AI resulted in an increased hazard of pregnancy by $38 \%$, which reduced the median days to pregnancy by 21 days. Pregnant cows fed algae had increased expression of one of the two interferon-stimulated genes investigated, RTP4, in peripheral blood leukocytes, perhaps suggesting advanced embryo development, despite similar concentrations of progesterone in control and Algae pregnant cows during the first 19 days after insemination. Algae altered the profile of FA in milk fat and in the phospholipid fraction of plasma, particularly increasing the concentration of DHA and total n-3 FA, thereby indicating the incorporation of the supplemented FA into tissues. Feeding Algae reduced milk fat yield, but yields of milk and true protein increased, resulting in similar yields of energy-corrected milk between Algae and control cows. Collectively, results presented herein suggest that fat supplementation 
based on algae product to provide $10 \mathrm{~g}$ of DHA per cow per day improves the reproductive performance and alters tissue fatty acid composition. The benefits in reproduction might be associated with improvements in embryo development, potentially through improvements in embryo-maternal crosstalk.

\section{Declaration of interest}

The authors declare that there is no conflict of interest that could be perceived as prejudicing the impartiality of the research reported.

\section{Funding}

This work was supported in part by a grant award \# 13-E-9193 from Alltech Animal Nutrition and Health to José E P Santos. Letícia D P Sinedino was supported by a Doctoral Fellowship from the Coordination for the Improvement of Higher Education Personnel (CAPES) from the Brazilian Ministry of Education (Brasília, Brazil).

\section{Author contribution statement}

Letícia D P Sinedino, Paula M Honda and Letícia R L Souza conducted the animal and laboratory portions of the experiment. Adam L Lock assisted with laboratory analyses of fatty acids and manuscript preparation. Maurice P Boland, Charles R Staples, William W Thatcher and José E P Santos designed the experiment and assisted with preparation of the manuscript. Letícia D P Sinedino and José E P Santos conducted the statistical analyses and wrote the manuscript. All authors reviewed and approved the final version of the manuscript.

\section{Acknowledgements}

The authors thank the owner and staff from High Roller Dairy (Hanford, CA) for the use of their cows and facilities. The assistance of Thiago F Fabris, Gilson G Maia, Diandra Lezier (University of Florida, Gainesville, FL), Courtney Preseault (Michigan State University, East Lansing, MI) and Cesar Narciso (Sequoia Veterinary Services, Tulare, CA) is appreciated. The authors are grateful to Dr Amanda Gehman (Alltech Animal Nutrition and Health, Nicholasville, KY) for discussions during the conduct of the experiment.

\section{References}

Abayasekara DR \& Wathes DC 1999 Effects of altering dietary fatty acid composition on prostaglandin synthesis and fertility. Prostaglandins, Leukotrienes, and Essential Fatty Acids 61 275-287. (doi:10.1054/ plef.1999.0101)

Agren JJ, Julkunen A \& Pirttilä I 1992 Rapid separation of serum lipids for fatty acid analysis by a single aminopropyl column. Journal of Lipid Research 33 1871-1876.

Ambrose DJ, Kastelic JP, Corbett R, Pitney PA, Petit HV, Small JA \& Zalkovic P 2006 Lower pregnancy losses in lactating dairy cows fed a diet enriched in $\alpha$-linolenic acid. Journal of Dairy Science 89 3066-3074. (doi:10.3168/jds.S0022-0302(06)72581-4)
Bauman DE, Harvatine KJ \& Lock AL 2011 Nutrigenomics, rumen-derived bioactive fatty acids, and the regulation of milk fat synthesis. Annual Review of Nutrition 31 299-319. (doi:10.1146/annurev.nutr.012809.104648)

Bhaswanta M, Poudyalb H \& Brown L 2015 Mechanisms of enhanced insulin secretion and sensitivity with n-3 unsaturated fatty acids. Journal of Nutritional Biochemistry 26 571-584. (doi:10.1016/j.jnutbio.2015.02.001)

Bilby TR, Guzeloglu A, MacLaren LA, Staples CR \& Thatcher WW 2006a Pregnancy, bovine somatotropin, and dietary $n-3$ fatty acids in lactating dairy cows: II. Endometrial gene expression related to maintenance of pregnancy. Journal of Dairy Science 89 3375-3385. (doi:10.3168/jds. S0022-0302(06)72374-8)

Bilby TR, Sozzi A, Lopez MM, Silvestre FT, Ealy AD, Staples CR \& Thatcher WW 2006b Pregnancy, bovine somatotropin, and dietary n-3 fatty acids in lactating dairy cows: I. Ovarian, conceptus, and growth hormoneinsulin-like growth factor system responses. Journal of Dairy Science 89 3360-3374. (doi:10.3168/jds.S0022-0302(06)72373-6)

Boerman JP \& Lock AL 2014 Effect of unsaturated fatty acids and triglycerides from soybeans on milk fat synthesis and biohydrogenation intermediates in dairy cattle. Journal of Dairy Science 97 7031-7042. (doi:10.3168/jds.2014-7966)

Brooks KE, Burns GW \& Spencer TE 2015 Peroxisome proliferator activator receptor gamma (PPARG) regulates conceptus elongation in sheep. Biology of Reproduction 92 42. (doi:10.1095/biolreprod.114.123877)

Childs S, Hennessy AA, Sreenan JM, Whates DC, Cheng Z, Stanton C, Diskin MG \& Kenny DA 2008 Effect of level of dietary n-3 polyunsaturated fatty acid supplementation on systemic and tissue fatty acid concentrations and on selected reproductive variables in cattle. Theriogenology $\mathbf{7 0}$ 595-611. (doi:10.1016/j.theriogenology.2008.04.002)

Dorniak P, Bazer FW \& Spencer TE 2011 Prostaglandins regulate conceptus elongation and mediate effects of interferon tau on the ovine uterine endometrium. Biology of Reproduction 84 1119-1127. (doi:10.1095/ biolreprod.110.089979)

Elanco 2009 The 5-Point Body Condition Scoring System, Document AI 10752. Greenfield, IN, USA: Elanco Animal Health. (Available at: https:// www.elanco.us/pdfs/ai10752-body-condition-score-insert.pdf).

Folch J, Lees M \& Stanley GHS 1957 A simple method for the isolation and purification of total lipids from animal tissues. Journal of Biological Chemistry 226 497-509.

Gifford CA, Assiri AM, Satterfield MC, Spencer TE \& Ott TL 2008 Receptor transporter protein 4 (RTP4) in endometrium, ovary, and peripheral blood leukocytes of pregnant and cyclic ewes. Biology of Reproduction 79 518-524. (doi:10.1095/biolreprod.108.069468)

Giordano E \& Visioli F 2014 Long-chain omega 3 fatty acids: molecular bases of potential antioxidant actions. Prostaglandins Leukotrienes and Essential Fatty Acids 90 1-4. (doi:10.1016/j.plefa.2013.11.002)

Greco LF, Neves Neto JT, Pedrico A, Lima FS, Bisinotto RS, Martinez N, Ribeiro ES, Thatcher WW, Staples CR \& Santos JEP 2014 Effects of altering the dietary ratio of n-6 to n-3 fatty acids on luteolytic mechanism in dairy cows. Journal of Dairy Science 97 (E-Supplement 1) 259. (doi:10.3168/jds.2013-7051)

Greco LF, Neves Neto JT, Pedrico A, Ferrazza RA, Lima FS, Bisinotto RS, Martinez N, Garcia M, Ribeiro ES, Gomes GC et al. 2015 Effects of altering the ratio of dietary n- 6 to $n-3$ fatty acids on performance and inflammatory responses to a lipopolysaccharide challenge in lactating Holstein cows. Journal of Dairy Science 98 1-16. (doi:10.3168/jds.2014-8433)

Green JC, Okamura CS, Poock SE \& Lucy MC 2010 Measurement of interferon-tau (IFN-tau) stimulated gene expression in blood leukocytes for pregnancy diagnosis within 18-20 d after insemination in dairy cattle. Animal Reproduction Science 121 24-33. (doi:10.1016/j. anireprosci.2010.05.010)

Gobert M, Martin B, Ferlay A, Chilliard Y, Graulet B, Pradel P, Bauchart D \& Durand D 2009 Plant polyphenols associated with vitamin E can reduce plasma lipoperoxidation in dairy cows given n-3 polyunsaturated fatty acids. Journal of Dairy Science 92 6095-6104. (doi:10.3168/jds.2009-2087)

Harvatine KJ \& Allen MS 2006 Effects of fatty acid supplements on feed intake, and feeding and chewing behavior of lactating dairy cows. Journal of Dairy Science 89 1104-1112. (doi:10.3168/jds.S00220302(06)72178-6)

Horsley CN, Aloqaily BH, Hernandez Gifford JA \& Gifford CA 2016 Receptor (chemosensory) transporter protein-4 expression and regulation in bovine granulosa cells. Journal of Animal Science 94 (E-Supplement 5) 102. (doi:10.2527/jam2016-0215) 
Hostens M, Fievez V, Vlaeminck B, Buyse J, Leroy J, Piepers S, De Vliegher S \& Opsomer G 2011 The effect of marine algae in the ration of highyielding dairy cows during transition on metabolic parameters in serum and follicular fluid around parturition. Journal of Dairy Science 94 4603-4615. (doi:10.3168/jds.2010-3899)

Jahani-Moghadam M, Mahjoubi E \& Dirandeh E 2015 Effect of linseed feeding on blood metabolites, incidence of cystic follicles, and productive and reproductive performance in fresh Holstein dairy cows. Journal of Dairy Science 98 1828-1835. (doi:10.3168/jds.2014-8789)

Johnsen GM, Basak S, Weedon-Fekjaer MS, Staff AC \& Duttaroy AK 2011 Docosahexaenoic acid stimulates tube formation in first trimester trophoblast cells, HTR8/SVneo. Placenta 32 626-632. (doi:10.1016/j. placenta.2011.06.009)

Jones ML, Mark PJ, Mori TA, Keelan JA \& Waddell BJ 2013 Maternal dietary omega-3 fatty acid supplementation reduces placental oxidative stress and increases fetal and placental growth in the rat. Biology of Reproduction 88 73. (doi:10.1095/biolreprod.112.103754)

Jørgensen E \& Pedersen AR 1998 How to obtain those nasty standard errors from transformed data - and why they should not be used. In Biometry Research Unit - Internal Report 7, p 20. Aarhus, Denmark: Danish Institute of Agricultural Sciences.

Livak KJ \& Schmittgen TD 2001 Analysis of relative gene expression data using real-time quantitative PCR and the 2(T)(-Delta Delta C) method. Methods 25 402-408. (doi:10.1006/meth.2001.1262)

Lock AL, Preseault CL, Rico JE, DeLand KE \& Allen MS 2013 Feeding a C16:0-enriched fat supplement increased the yield of milk fat and improved feed efficiency. Journal of Dairy Science 96 6650-6659. (doi:10.3168/jds.2013-6892)

Matsuyama S, Kojima T, Kato S \& Kimura K 2012 Relationship between quantity of IFNT estimated by IFN-stimulated gene expression in peripheral blood mononuclear cells and bovine embryonic mortality after AI or ET. Reproductive Biology and Endocrinology $\mathbf{1 0} 21$. (doi:10.1186/1477-7827-10-21)

Mattos R, Guzeloglu A, Badinga L, Staples CR \& Thatcher WW 2003 Polyunsaturated fatty acids and bovine interferon-tau modify phorbol ester-induced secretion of prostaglandin F2 alpha and expression of prostaglandin endoperoxide synthase- 2 and phospholipase-A2 in bovine endometrial cells. Biology of Reproduction 69 780-787. (doi:10.1095/ biolreprod.102.015057)

Mattos R, Staples CR, Arteche A, Wiltbank MC, Diaz FJ, Jenkins TC \& Thatcher WW 2004 The effects of feeding fish oil on uterine secretion of $\mathrm{PGF}_{2 \alpha^{\prime}}$ milk composition, and metabolic status of periparturient Holstein cows. Journal of Dairy Science 87 921-932. (doi:10.3168/jds.S0022 0302(04)73236-1)

Moussavi AR, Gilbert RO, Overton TR, Bauman DE \& Butler WR 2007a Effects of feeding fish meal and n-3 fatty acids on ovarian and uterine responses in early lactating dairy cows. Journal of Dairy Science $\mathbf{9 0}$ 145-154. (doi:10.3168/jds.S0022-0302(07)72616-4)

Moussavi AR, Gilbert RO, Overton TR, Bauman DE \& Butler WR 2007b Effects of feeding fish meal and $n-3$ fatty acids on milk yield and metabolic responses in early lactating dairy cows. Journal of Dairy Science 90 136-144. (doi:10.3168/jds.S0022-0302(07)72615-2)

National Research Council 2001 Nutrient Requirements of Dairy Cattle, 7th rev. ed. Washington, DC, USA: Natl. Acad. Press.

Oliveira JF, Henkes LE, Ashley RL, Purcell SH, Smirnova NP, Veeramachaneni DN, Anthony RV \& Hansen TR 2008 Expression of interferon (IFN)stimulated genes in extrauterine tissues during early pregnancy in sheep is the consequence of endocrine IFN-tau release from the uterine vein. Endocrinology 149 1252-1259. (doi:10.1210/en.2007-0863)

Petit HV, Dewhurst RJ, Proulx JG, Khalid M, Haresign W \& Twagiramungu H 2001 Milk production, milk composition, and reproductive function of dairy cows fed different fats. Canadian Journal of Animal Science $\mathbf{8 7}$ 263-271. (doi:10.4141/A00-096)

Piantoni P, LockAL \& Allen MS 2013 Palmitic acid increased yields of milk and milk fat and nutrient digestibility across production level of lactating cows. Journal of Dairy Science 96 7143-7154. (doi:10.3168/jds.2013-6680)

Rabiee AR, Breinhild K, Scott W, Golder HM, Block E \& Lean IJ 2012 Effect of fat additions to diets of dairy cattle on milk production and components: a meta-analysis and metaregression. Journal of Dairy Science 95 3225-3247. (doi:10.3168/jds.2011-4895)

Ribeiro ES, Bruno RGS, Farias AM, Hernández-Rivera JA, Gomes GC, Surjus R, Sasser G, Keisler DH, Bilby TR, Thatcher WW et al. 2014
Low doses of bovine somatotropin enhance conceptus development and fertility in lactating dairy cows. Biology of Reproduction 9010. (doi:10.1095/biolreprod.113.114694)

Ribeiro ES, Santos JEP \& Thatcher WW 2016a Role of lipids on elongation of the preimplantation conceptus in ruminants. Reproduction 152 R115-R126. (doi:10.1530/REP-16-0104)

Ribeiro ES, Greco LF, Bisinotto RS, Lima FS, Thatcher WW \& Santos JEP $2016 b$ Biology of preimplantation conceptus at the onset of elongation in dairy cows. Biology of Reproduction 94 97. (doi:10.1095/ biolreprod.115.134908)

Ribeiro ES, Gomes G, Greco LF, Cerri RL, Vieira-Neto A, Monteiro PL Jr, Lima FS, Bisinotto RS, Thatcher WW \& Santos JEP 2016c Carryover effect of postpartum inflammatory diseases on developmental biology and fertility in lactating dairy cows. Journal of Dairy Science $\mathbf{9 9}$ 2201-2220. (doi:10.3168/jds.2015-10337)

Rodney RM, Celi P, Scott W, Breinhild K \& Lean IJ 2015 Effects of dietary fat on fertility of dairy cattle: a meta-analysis and meta-regression. Journal of Dairy Science 98 5601-5620. (doi:10.3168/jds.2015-9528)

Samstein RM, Josefowicz SZ, Arvey A, Treuting PM \& Rudensky AY 2012 Extrathimic generation of regulatory $\mathrm{T}$ cells in placental mammals mitigates maternal-fetal conflict. Cell 150 29-38. (doi:10.1016/j. cell.2012.05.031)

Santos JEP, Bilby TR, Thatcher WW, Staples CR \& Silvestre FT 2008 Long chain fatty acids of diet as factors influencing reproduction in cattle. Reproduction in Domestic Animals 43 23-30. (doi:10.1111/j.14390531.2008.01139.x)

Silvestre FT, Carvalho TSM, Francisco N, Santos JEP, Staples CR, Jenkins T \& Thatcher WW 2011a Effects of differential supplementation of fatty acids during the peripartum and breeding periods of Holstein cows: I. Uterine and metabolic responses, reproduction, and lactation. Journal of Dairy Science 94 189-204. (doi:10.3168/jds.2010-3370)

Silvestre FT, Carvalho TSM, Crawford PC, Santos JEP, Staples CR, Jenkins T \& Thatcher WW 2011b Effects of differential supplementation of fatty acids during the peripartum and breeding periods of Holstein cows: II. Neutrophil fatty acids and function, and acute phase proteins. Journal of Dairy Science 94 2285-2301. (doi:10.3168/jds.2010-3371)

Stamey JA, Shepherd DM, de Veth MJ \& Corl BA 2012 Use of algae or algal oil rich in n-3 fatty acids as a feed supplement for dairy cattle. Journal of Dairy Science 95 5269-5275. (doi:10.3168/jds.2012-5412)

Staples CR, Burke JM \& Thatcher WW 1998 Influence of supplemental fats on reproductive tissues and performance of lactating cows. Journal of Dairy Science 81 856-871. (doi:10.3168/jds.S0022-0302(98)75644-9)

Sturmey G, Reis A, Leese HJ \& McEvoy TG 2009 Role of fatty acids in energy provision during oocyte maturation and early embryo development. Reproduction of Domestic Animals 44 (Supplement 3) 50-58. (doi:10.1111/j.1439-0531.2009.01402.x)

Wahle KW, Rotondo D \& Heys SD 2003 Polyunsaturated fatty acids and gene expression in mammalian systems. Proceedings of the Nutrition Society 62 349-360. (doi:10.1079/PNS2003249)

Wilson KS, Hernandez Gifford JA, Ott TL \& Gifford CA 2016 Protein expression and localization of receptor (chemosensory) transporter protein 4 in the endometrium during early pregnancy in sheep and cattle. Journal of Animal Science 94 (E-Supplement 5) 102. (doi:10.2527/ jam2016-0216)

Wullepit N, Hostens M, Ginnebergea C, Fieveza V, Opsomer G, Fremaut D \& De Smeta S 2012 Influence of a marine algae supplementation on the oxidative status of plasma in dairy cows during the periparturient period. Preventive Veterinary Medicine 103 298-303. (doi:10.1016/j. prevetmed.2011.09.007)

Yuan JS, Reed A, Chen F \& Stewart CN 2006 Statistical analysis of real-time PCR data. BMC Bioinformatics 7 1-12. (doi:10.1186/1471-2105-7-1)

Zachut M, Arieli A, Lehrer H, Argov N \& Moallem U 2008 Dietary unsaturated fatty acids influence preovulatory follicle characteristics in dairy cows. Reproduction 135 683-692. (doi:10.1530/REP-07-0556)

Received 26 November 2016

First decision 22 December 2016

Revised manuscript received 11 January 2017

Accepted 21 February 2017 